BENJAMIN SUTER

\title{
APPOINTMENT, DISCIPLINE AND REMOVAL OF JUDGES: A COMPARISON OF THE SWISS AND NEW ZEALAND JUDICIARIES
}

\author{
LLM RESEARCH PAPER
}

LAWS 522: JUDICIARY

FACULTY OF LAW

TE WHARE WĀNANGA O TE ŨPOKO O TE IKA A MĀUI

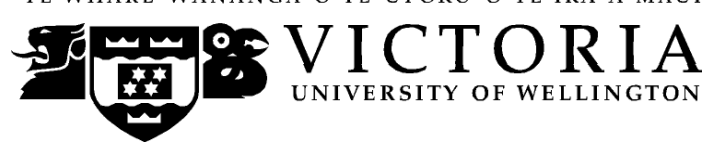

2014 


\section{Table of Contents}

I. Introduction $\quad 4$

II. Switzerland's legal and political systems in a nutshell $\mathbf{5}$

A. Switzerland's legal system $\quad 5$

B. Switzerland's political system $\quad 7$

$\begin{array}{lll}\text { C. Switzerland's federalism } & 7\end{array}$

III. Structure and powers of the judiciaries $\quad 8$

A. Switzerland's court structure $\quad 8$

1. The fundamental distinction between public law and private law 8

2. The Federal courts 9

3. The courts of the Cantons 9

B. New Zealand's court structure $\quad 10$

C. The powers of the judiciary 11

1. The powers of the Swiss judges 11

2. The powers of the New Zealand judges 12

IV. Appointment of judges 13

A. Who is eligible to be a judge? 13

1. Who is eligible to be a Swiss judge? 13

2. Who is eligible to be a New Zealand judge? 14

3. The Swiss debate on lay judges 15

4. Jury trials 15

5. The role of law clerks 16

B. Who appoints the judges? 18

1. Who appoints the judges in New Zealand? 18

2. Who appoints the judges in Switzerland? 19

C. By which criteria are judges selected? 23

D. The take on appointment boards 26

E. The take on political influence 28

V. Discipline and removal from office of judges 33

A. Term of office and re-election of Swiss judges 33

B. Obligations of Swiss judges vis-à vis their parties 36

C. A de facto tenure? 37

D. Discipline and removal from office of Swiss judges 42

1. Discipline and removal from office of Federal judges 42

2. No discipline or removal from office of Federal Supreme Court judges 46

3. Discipline and removal from office in the Cantons 47

E. Discipline and removal from office of New Zealand judges 48

VI. Conclusions 


\begin{abstract}
This paper gives an overview of the legal system of Switzerland and then compares the judiciaries of Switzerland and New Zealand. As far as Switzerland is concerned, it covers both the system of the Swiss Federation and the systems in the Cantons. After analysing the powers enjoyed by the judiciary via the legislature, the paper examines the appointment of judges in detail. The author explains how in Switzerland openly political and other considerations are weighed in the course of electing judges and how the appointment of lay judges is balanced with an active role of law clerks. In contrast, New Zealand has a proud tradition of apolitical judicial appointments that are made solely based on merit. The author criticises that Swiss judges are elected for a term of office, whereas New Zealand judges enjoy the security of tenure and thus, a greater judicial independence. Lastly, the paper covers the removal and discipline of judges, where the author, while he commends the recent reform in New Zealand, speaks out for a system where the ultimate decision is given to an independent judicial body rather than a parliament.
\end{abstract}

\title{
Word length
}

The text of this paper (excluding abstract, table of contents, footnotes and bibliography) comprises 14,887 words.

\section{Subjects and Topics}

Judicial independence

Appointment of judges

Discipline and removal of judges 


\section{Introduction}

This paper aims to compare the judiciaries of New Zealand and Switzerland focusing on two selected topics: appointment of judges and discipline and removal of judges. How a society appoints and, if at all, removes its judges from office provides important information about the perceived role and standing of the judiciary.

For the benefit of the reader unfamiliar with Switzerland's legal and political systems this paper begins with displaying their main features, as understanding them is a prerequisite to understanding many of the issues covered in this paper. It then compares first the two countries' court structure and the powers granted to the respective judiciaries.

The paper then examines in depth the procedures of appointment that are followed and the goals that are sought to be achieved by following the procedures. Judges in Switzerland, both on the Federal level and in the Cantons, are not appointed by the Government but elected - either by the parliament or by the people, and following political considerations. In contrast, most New Zealand judges are appointed by the Governor-General following the advice of the Attorney-General, who selects a candidate based on merit. Unlike New Zealand judges, Swiss judges do not enjoy the protection of tenure: They are elected for a term of office between four and ten years.

Then the procedures of dismissal of judges are covered. While the appointment procedures in New Zealand and in Switzerland differ fundamentally in almost every aspect, some similarities can be found when it comes to removal and discipline. The grounds for removal are largely the same, whereas the proceedings are different from each other in many ways, even though in both countries the parliaments ultimately decide on whether to remove a judge from office.

The Swiss Federation consists of 26 Cantons, each with a judiciary on their own. This paper will cover consistently the Swiss federal judiciary, whereas the judiciary of the Cantons will be dealt with somewhat superficially: This paper will attempt to describe the-often diverse-legislations found in the Cantons by choosing a few illustrative examples. 
The Federal Government has translated some of the most important Federal acts to English. Given that English is not an official language of Switzerland, these translations have no legal force and are for information purposes only. They are however published on the official website of the Federation together with the official versions of the acts, which is why they are hereinafter referred to as "semi-official" translations. Whenever such an English translation of a Federal act is available, this paper will make use of it and indicate it in a footnote.

\section{Switzerland's legal and political systems in a nutshell}

\section{A. Switzerland's legal system}

Switzerland can be described as a federal directorial republic. It is a federation consisting of 26 states, which are called "Cantons". ${ }^{1}$ The English translation of the Swiss Federal Constitution refers to it as the "Swiss Confederation", which is an adaption of the official names in French (Confédération suisse), Italian (Confederazione Svizzera) and Romansh (Confederaziun svizra). ${ }^{2}$ From a public law perspective, however, the term is not accurate, as Switzerland is considered a federation rather than a confederation (which it used to be until 1848). ${ }^{3}$ The German name, by the way, is Schweizerische Eidgenossenschaft, a historic term meaning something along the lines of "Swiss association of those bound together by oath [as opposed to a feudal authority]".

The federal government is the Bundesrat (Conseil fédéral, Consiglio federale, Cussegl federal), which will be hereinafter referred to as "Federal Council", a college of seven ministers who jointly exercise the powers of the head of state and government. The

\footnotetext{
${ }^{1}$ Bundesverfassung der Schweizerischen Eidgenossenschaft 1999, art 1 (translation: Federal Constitution of the Swiss Confederation) as per the semi-official translation on <http://www.admin.ch/opc/en/classifiedcompilation/19995395/index.html>.

${ }^{2}$ Bundesverfassung der Schweizerischen Eidgenossenschaft 1999, art 1 (translation: Federal Constitution of the Swiss Confederation) as per the semi-official translation on <http://www.admin.ch/opc/en/classifiedcompilation/19995395/index.html>.

${ }^{3}$ Andreas Kley Historisches Lexikon der Schweiz/Dictionnaire historique de la Suisse (online ed, 2014) Bundesstaat <http://www.hls-dhs-dss.ch/textes/d/D9801.php> (translation: Historic Encyclopaedia of Switzerland ... Federation).
} 
Federal parliament elects the Federal Councillors for a term of office of four years. ${ }^{4}$ There is no possibility of impeachment or removal. It is even very rare that Federal Councillors are refused re-election: It happened only four times since the establishment of the Federal Council in $1848 .^{5}$

The Federal parliament is the Bundesversammlung (Assemblée fédérale, Assemblea federale, Assamblea federala), which will be hereinafter referred to as "Federal Assembly". It comprises two chambers, the Nationalrat (Conseil national, Consiglio nazionale, Cussegl naziunal; hereinafter: "National Council”) and the Ständerat (Conseil des Etats, Consiglio degli Stati, Cussegl dals chantuns; hereinafter: "Council of States"). In the National Council, which comprises a total of 200 members, the number of each Canton's representatives corresponds to its population, whereas in the Council of State, in principle, each Canton is represented by two members. For historic reasons though, six Cantons are only allowed to elect one State Councillor. Both chambers are of equal standing. ${ }^{6}$

The law-making powers lie with the Federal Assembly and the people. Federal legislation has to pass the following hurdles: Amendments of the constitution must first be approved by both the National Council and the Council of States. Then both the majority of the people and the majority of the Cantons must approve them in a public vote. ${ }^{7}$ A Federal act must be approved by both the National Council and the Council of States. The act is submitted to a vote of the people if 50,000 persons who are eligible to vote or eight Cantons request it within 100 days of the official publication of the enactment. ${ }^{8}$ This is referred to as "optional referendum" and does not require the approval of the majority of the Cantons.

\footnotetext{
${ }^{4}$ Bundesverfassung der Schweizerischen Eidgenossenschaft 1999, art 175 (translation: Federal Constitution of the Swiss Confederation).

${ }^{5}$ See Wikipedia „Swiss Federal Council election“ $<$ http://en.wikipedia.org/wiki/Federal_Council_Switzerland_election>.

6 Bundesverfassung der Schweizerischen Eidgenossenschaft 1999, art 148(2) (translation: Federal Constitution of the Swiss Confederation).

${ }^{7}$ Bundesverfassung der Schweizerischen Eidgenossenschaft 1999, art 140(1)(a) and 142(2) (translation: Federal Constitution of the Swiss Confederation).

8 Bundesverfassung der Schweizerischen Eidgenossenschaft 1999, art 141(1) (translation: Federal Constitution of the Swiss Confederation).
} 
Each of the Cantons has its own written constitution, its own government, parliament and courts. The Cantonal governments are called either Executive Council or Council of State. Similar to the Federal Council, they are organised as a college of five or seven ministers jointly heading the administration. Other than the Federal Council however, the people elect the Cantonal governments directly.

\section{B. Switzerland's political system}

Switzerland has a multi-party system with four parties reaching an electoral share over $10 \%$ and seven parties ranking over 5\% (both as per the last federal election in 2011). The four most popular parties have been in that position for more than fifty years. The highest electoral share one single party ever reached since the principle of proportional representation was established in 1919 were the $28.9 \%$ of votes received by the rightwing Schweizerische Volkspartei (SVP) ${ }^{9}$ in 2007.

The Federal Assembly usually elects the Federal Councillors out of these four parties according to their electoral share. Thus, for more than fifty years the Swiss Federation has been governed by a (loose) coalition of the same four biggest parties.

The same holds true for the Cantons in the sense that their governments are not composed by the winner of the election. Given that the people elect the Cantonal governments, the composition of the governments reflects the electoral share of the parties in the respective Canton.

\section{Switzerland's federalism}

The Swiss Constitution provides a division of powers between the Federation and the Cantons: „The Confederation shall fulfil the duties that are assigned to it by Federal Constitution“. ${ }^{10}$ The duties of the Federation are enumerated in the Swiss Constitution in articles 54 through 135. Any matter not mentioned therein falls into the power of the Cantons.

\footnotetext{
${ }^{9}$ Translation: Swiss People's Party.

10 Bundesverfassung der Schweizerischen Eidgenossenschaft 1999, art 42(1) (translation: Federal Constitution of the Swiss Confederation) as per the semi-official translation on <http://www.admin.ch/opc/en/classified-compilation/19995395/index.html>.
} 
Usually, the implementation of Federal law is a task of the Cantons. ${ }^{11}$ Exceptions include, inter alia, the military, customs and foreign affairs.

Federal law takes precedence over any conflicting provision of Cantonal law. ${ }^{12}$

\section{Structure and powers of the judiciaries}

\section{A. Switzerland's court structure}

1. The fundamental distinction between public law and private law

Both the Cantons and the Federation have established their own courts.

Their scopes of jurisdiction are influenced by the differentiation of public law and private law, which is fundamental in Switzerland. Private law is the law governing the relationships between individuals (natural persons and organisations). Public law governs relationships between individuals and the state.

Private law is for the most part Federal law, as it has been codified in Federal acts. The same holds true for criminal law. In addition, the court proceedings in both private law cases and criminal law cases are governed by Federal procedural law.

Public law is Federal law where the Federation is competent to legislate. Where a matter has not been assigned to the Federation for regulation, cantonal law applies.

Given that the implementation of Federal law is a task of the Cantons, the courts of the Cantons often apply Federal law. Most of all, this is true in criminal or private law cases where the jurisdiction of the Federal Criminal Court and the Federal Patent Court is very limited. In contrast, in matters of Federal public law, much more cases are decided by the Federal Administrative Court, but still many cases involving Federal public law are heard by Cantonal courts.

\footnotetext{
${ }^{11}$ Bundesverfassung der Schweizerischen Eidgenossenschaft 1999, art 46 (translation: Federal Constitution of the Swiss Confederation).

12 Bundesverfassung der Schweizerischen Eidgenossenschaft 1999, art 49(1) (translation: Federal Constitution of the Swiss Confederation).
} 


\section{The Federal courts}

Until recently there used to be only one Federal court, the Swiss Federal Supreme Court (Bundesgericht, Tribunal fédéral, Tribunale federale, Tribunal federal; hereinafter: "Federal Supreme Court"). However, in the course of a major reform of the Federal judicature a few years ago some further Federal courts were established: the Federal Administrative Court, the Federal Criminal Court and the Federal Patent Court.

The Federal Criminal Court and the Federal Patent Court were established as specialised courts of original jurisdiction. ${ }^{13}$

The Federal Administrative Court hears disputes originating in the Federal administration. ${ }^{14}$ It thus acts as a court of appeal with regard to decisions made by the Federal administration.

The Federal Supreme Court is the supreme court of the land. It acts as a final court of appeal in all matters of private law and criminal law and in most matters of public law. Some exceptions apply with regard to decisions by the Federal Administrative Court. ${ }^{15}$

\section{The courts of the Cantons}

The court structures of the Cantons are all similar to each other. In all Cantons there are courts of lower instance, which hear private law and criminal law cases. These courts are usually called District Courts. In some Cantons criminal law cases are brought before a specialised Criminal Court.

All Cantons have established Courts of Appeal having jurisdiction both in private law cases and in criminal law cases.

13 Bundesverfassung der Schweizerischen Eidgenossenschaft 1999, art 191a(1) (translation: Federal Constitution of the Swiss Confederation); Bundesgesetz über die Organisation der Strafbehörden des Bundes 2010, art 35 (translation: Federal Act on the Organisation of the Federal Criminal Authorities); Bundesgesetz über das Bundespatentgericht 2009, art 1 (translation: Federal Act on the Federal Patent Court).

14 Bundesgesetz über das Bundesverwaltungsgericht 2005, art 1 (translation: Federal Act on the Federal Administrative Court).

15 Bundesgesetz über das Bundesgericht 2005, art 83 (translation: Federal Act on the Federal Supreme Court). 
As a matter of Federal law ${ }^{16}$, all Cantons must appoint an administrative court, which hears appeals in matters of public law. While some Cantons have established specialised Administrative Courts, others have appointed the Courts of Appeal as their administrative courts.

The procedural law applied by the courts of the Cantons is now mostly Federal law, as both a Federal Civil Procedure Code and a Federal Criminal Procedure Code were enacted in 2011. In public law cases however, the procedure is still a matter of the Cantonal law.

\section{B. New Zealand's court structure}

There are four courts of general jurisdiction in New Zealand: the District Courts; the High Court; the Court of Appeal and the Supreme Court. In addition, there are a number of specialised courts such as the Family Court, the Youth Court, the Employment Court and the Māori Land Court. ${ }^{17}$

The New Zealand Supreme Court was created only in 2003. Until then, the final court of appeal for New Zealand had been the Judicial Committee of the Privy Council, a judicial body sitting in London. ${ }^{18}$

The Court of Appeal has both civil and criminal appellate jurisdiction. It hears appeals from the High Court and, exceptionally, from inferior courts. ${ }^{19}$

The High Court enjoys both general original jurisdiction and appellate jurisdiction. In the latter role, it hears appeals from the District Courts. The High Court's original jurisdiction includes all matters that fall outside the statutory jurisdiction of the District Courts. ${ }^{20}$

\footnotetext{
${ }^{16}$ Bundesgesetz über das Bundesgericht 2005, art 86(2) (translation: Federal Act on the Federal Supreme Court).

17 Duncan Webb, Katherine Sanders and Paul Scott The New Zealand Legal System: Structures and Processes (5th ed, LexisNexis, Wellington, 2010) at 250.

${ }^{18}$ At 260.

${ }^{19}$ At 265.

${ }^{20}$ At 267.
} 


\section{The powers of the judiciary}

1. The powers of the Swiss judges

\section{a) The two forms of judicial powers}

Two forms of powers of the Swiss judiciary vis-à-vis the legislature may be distinguished. The first one can be called "judicial review": the power to review a law in concreto, while examining a concrete decision that was rendered applying the law. In Swiss legal tradition, a court reviewing a law in concreto does not have the power to quash it, but the court may express that it deems the law invalid and accordingly not apply it in the case at hand.

The second power is referred to as "constitutional jurisdiction": the power of a court to review a law in the abstract and quash it, without it being applied in a decision.

\section{b) The courts of the Cantons and the lower Federal courts}

All Swiss courts may exercise judicial review, in particular examine if a law is in conflict with the constitution. This system is called "diffused constitutional jurisdiction".

Not all Swiss courts have constitutional jurisdiction, though. In the Cantons, some Courts of Appeal act as constitutional courts and may thus, upon appeal by any resident of the Canton, quash a law that is in conflict with the constitution or Federal law. In most Cantons, though, such constitutional jurisdiction is limited to legislation that was set by communal authorities or the Cantonal government, whereas acts of the Cantonal parliament are not subject to constitutional jurisdiction by the courts of the Cantons.

\section{c) The Federal Supreme Court}

As mentioned before, the Federal Supreme Court, in its first function, acts as a final court of appeal for any case decided by lower Federal courts or higher Cantonal courts. In its second function, the Federal Supreme Court safeguards the supremacy of Federal law over Cantonal law. Therefore, the Federal Supreme Court must have constitutional jurisdiction on all Cantonal legislation. ${ }^{21}$

\footnotetext{
${ }^{21}$ See Bundesgesetz über das Bundesgericht 2005, art 82(2) and 87 (translation: Federal Act on the Federal Supreme Court).
} 
The Federal Supreme Court does not have constitutional jurisdiction on Federal law though. While it is well established that the Federal Supreme Court may review all kinds of federal legislation, the court must apply Federal acts even if they are in conflict with the constitution. This is provided in art 190 of the Swiss Constitution: "The Federal Supreme Court and the other judicial authorities apply the federal acts and international law."22

The question arises which should in case of conflict prevail: Federal acts or international law. The constitution provides no answer. The Federal Supreme Court traditionally held that international law in principle should prevail, as it must be assumed that the legislator intended to comply with Switzerland's international obligations. An exception applies, however, if the legislator intentionally enacted a Federal law that is in conflict with international law. This principle was established in the famous Schubert case. ${ }^{23}$ There is a counter-exception to Schubert, though: In a number of recent cases the Federal Supreme Court held that international law must prevail in cases where the international law is aimed at the protection of human rights (such as the European Convention on Human Rights). ${ }^{24}$ Whether it extends to other international treaties remains unclear.

\section{The powers of the New Zealand judges}

The High Court inherits the inherent jurisdiction and powers of the courts of common law and equity in England. Among those is the power to ensure that public bodies act within the boundaries set by law. ${ }^{25}$ This is called "judicial review", as far as the validity of delegated legislation is concerned. ${ }^{26}$ Traditionally, as a matter of Parliamentary sovereignty, courts do not have the power to review Acts of Parliament. ${ }^{27}$ In recent times,

22 Bundesverfassung der Schweizerischen Eidgenossenschaft 1999, art 190 (translation: Federal Constitution of the Swiss Confederation) as per the semi-official translation on <http://www.admin.ch/opc/en/classified-compilation/19995395/index.html>.

${ }^{23}$ See Schubert v Canton of Ticino [1973] 99 Ib BGE/ATF 39.

${ }^{24}$ See A v Federal Council [1999] 125 II BGE/ATF 417; Eidgenössische Zollverwaltung v X [2012] 138 II BGE/ATF 524.

${ }^{25}$ Webb, Sanders and Scott, above n 17, at 267.

${ }^{26}$ At 87.

${ }^{27}$ At 125 and 131. 
though, two eminent judges indicated in extra-judicial statements some scepticism towards the idea of completely unrestrained powers of Parliament. ${ }^{28}$ Nevertheless, the doctrine of Parliamentary sovereignty continues to be the prevailing view.

\section{Appointment of judges}

This paper will now examine and compare how judicial appointments are made in Switzerland and New Zealand. To that end, this paper will first examine the requirements in legislation to be a judge and the question of who is granted the power to make the appointments. The paper will then set out the criteria following which judges are selected from the pool of candidates before finally turning to two topics deserving a separate treatment: each country's stance on appointment boards and on political influence.

\section{A. Who is eligible to be a judge?}

\section{Who is eligible to be a Swiss judge?}

The formal requirements to be a Federal court judge are scant: Any person eligible to vote, that is to say: anyone over the age of 18 who is not incapacitated, may be appointed as Federal court judge. ${ }^{29}$

In some Cantons, for instance in the Canton of Zurich, eligibility to vote is the sole formal requirement to be a judge as well. However, a law degree or even a bar exam is in many Cantons required from full-time judges, from presiding judges or from judges of courts of appeal. In the Canton of Aargau, which recently reformed its law on the organisation of the judiciary, the presiding judges of the District Courts and the judges of the Court of Appeal must meet a higher threshold: They must both hold a bar exam and have been working as a lawyer for five years. In the Canton of Fribourg/Freiburg, fulltime judges must have a law degree and sufficient practical experience. In other Cantons, such as the Cantons of Basel-Stadt and Basel-Landschaft, only the presiding judges are required to hold a law degree. Only two Cantons, Lucerne and Zug, require all judges to hold a law degree.

\footnotetext{
${ }^{28}$ At 131.

${ }^{29}$ Bundesgesetz über das Bundesgericht 2005, art 5(2) (translation: Federal Act on the Federal Supreme Court).
} 
Lay judges are therefore still common in many Cantons. Historically, the introduction of lay judges in Europe was a product of the Enlightenment meant to counterbalance the legally educated judges who were appointed by the monarchs. In Switzerland however it had for the most part been due to the fact that academically trained lawyers were for a long time scant in rural regions. ${ }^{30}$

Typically, lay judges will only be part of a panel of judges, together with judges holding a law degree. It may happen though that a lay judge must act as a single judge as was the case in $X v$ Canton of Thurgau, where both the president and the vice-president of the district court had recused themselves. ${ }^{31}$ The Federal Supreme Court held that to have a case adjudicated by a lay judge is not in violation of the right to a fair trial as long as a trained law clerk participates in the management of the proceedings and the decisionmaking. ${ }^{32}$ The court noted that in the concerned Canton of Thurgau - as in many other Cantons - the law clerk may actively participate in the deliberations on the judgment. ${ }^{33}$

2. Who is eligible to be a New Zealand judge?

In New Zealand, the formal requirements for judges are considerably stricter. High Court judges must have held a practising certificate as a barrister or solicitor for at least seven years. ${ }^{34}$ The same rule applies to District Court judges who, however, are also eligible if they have been continuously employed as an officer of the responsible department or Ministry of Justice for a period of at least 10 years, and during that period have been employed for not less than 7 years as the Clerk or Registrar of a court, and are a barrister or solicitor who has been qualified for admission, or admitted, as such for not less than 7 years. $^{35}$

Court of Appeal judges as well as Supreme Court judges are required to be appointed as judges of the High Court and must therefore satisfy the same conditions. ${ }^{36}$

\footnotetext{
${ }^{30} X v$ Canton of Thurgau [2007] 134 I BGE/ATF 16 at 18.

${ }^{31}$ At 16.

${ }^{32}$ At 19.

${ }^{33}$ At 19.

${ }^{34}$ Judicature Act 1908 s 6.

${ }^{35}$ District Courts Act 1947 s 5(3).

${ }^{36}$ Judicature Act 1908, s 57; Supreme Court Act 2003 s 20.
} 


\section{The Swiss debate on lay judges}

There is no denying that lawyers are better suited for the bench than lay judges. Just recently, a newly elected lay judge came to realise after having been acting as a judge for some months that he did not meet the standards that he himself expected a judge to fulfil. ${ }^{37}$ Those in favour of lay judges usually argue that they bring common sense and experience of life to the courts and that they may add a different professional experience. A further argument that is put forward is that the judiciary as one of the three state powers should not be restricted to one profession only. ${ }^{38}$ These arguments are however simply testament to widespread prejudices of lawyers living in an ivory tower. While a court may indeed benefit from having access to professional experience gained outside the legal profession, a judge must first and foremost have sound knowledge of the law and the experience of applying it. Any other professional experience or experience of life, as enriching as it may be, can never replace the legal expertise. While these further experiences may sometimes help finding the right answers, only legal experience enables the judges to ask themselves the right questions.

\section{Jury trials}

The popularity of lay judges in Switzerland contrasts sharply with the abolition of jury trials. Until 2010, all but four Cantons had already abolished jury trials. Three more did so when adapting their legislation on the judiciary to the new Federal procedure codes. Only the Canton of Ticino in a public vote decided to hold on to some variation of jury courts (mixed panels of lawyers and lay members, with a majority of lay members). ${ }^{39}$

New Zealand on the other hand still offers to the parties of a trial the option of having their dispute adjudicated by a jury. This applies both to the accused person in criminal trials where the maximum penalty is three month's imprisonment or more and to the

\footnotetext{
${ }^{37}$ Brigitte Hürlimann "Der Polizist will nicht mehr richten" Neue Zürcher Zeitung (16 May 2014) at 15 (translation: "The policeman does not want to be a judge anymore").

38 Beat Grossrieder and Dominique Strebel "Justiz: Die Laien sterben langsam aus" Beobachter <http://www.beobachter.ch/justiz-behoerde/buerger-verwaltung/artikel/justiz_die-laien-sterben-langsamaus/> (translation: "Judiciary: The laypersons are dying out").

${ }^{39}$ Peter Jankovsky "Das Tessinervolk redet vor Gericht mit” Neue Zürcher Zeitung (13 December 2011) at 14 (translation: "The people of Ticino have their say in court").
} 
parties to a civil case where the amount claimed or the value of the chattel in dispute exceeds $\$ 3,000 .^{40}$ Jurors are mostly laypersons, as both judges and practising lawyers are disqualified from sitting on juries. ${ }^{41}$ In this way, juries ensure that a range of perspectives, experiences and knowledge are brought to bear in the decision-making and that contemporary community values are reflected in the decisions of the courts. ${ }^{42}$

It is submitted that lay judges and jurors serve a similar purpose: They both satisfy the people's need to be judged by their peers on the basis of contemporary community values. $^{43}$

\section{The role of law clerks}

Due to the popularity of lay judges in Switzerland, law clerks play an important role in the Swiss judiciary. In German they are called "Gerichtsschreiber" (literally: "court writer"), in French and Italian "gréffier" ("recording clerk") and "cancelliere" ("chancellor"). ${ }^{44}$ They are required to hold a law degree and many of them are admitted to the bar.

Historically, many judges were not lawyers. Until the $19^{\text {th }}$ century, especially in rural regions, law clerks were very often the only lawyers at courts. ${ }^{45}$ Writing the reasons for the judgment was therefore an important task of the law clerks, as the judges as laymen were often not capable to write legally correct judgments. ${ }^{46}$ In many Cantons, law clerks participate in the deliberations of the judges, where they may submit motions or counter-

\footnotetext{
${ }^{40}$ Judicature Act 1908, s 19A.

${ }^{41}$ Webb, Sanders and Scott, above n 17, at 293.

${ }^{42}$ Law Commission Delivering Justice For All: A Vision for New Zealand Court and Tribunals (R85 2004) at 181 .

${ }^{43}$ See Webb, Sanders and Scott, above n 17, at 293.

${ }^{44}$ Stefan Heimgartner "Der Richter und sein Schreiber" in Marianne Heer and others (eds) Toujours agité jamais abattu: Festschrift für Hans Wiprächtiger (Helbing Lichtenhahn, Basel, 2011) 295 at 297 (translation: "The judge and his clerk" in Always agitated - never disheartened: Festsschrift for Hans Wiprächtiger). The title of this text is a reference to Friedrich Dürrenmatt's famous novel "Der Richter und sein Henker" ("The judge and his hangman").

45 See Simon Netzle "Der Gerichtsschreiber - mehr Gericht als Schreiber?" <www.gerichtsschreiber.ch/pdf/geschichtliches.pdf> (translation: "The Court Clerk - more Court than Clerk?").

${ }^{46}$ Heimgartner, above n 44, at 298.
} 
motions as to the court's decision. This is referred to as law clerks having "beratende Stimme" ("voix consultative", "voto consultivo", "advisory vote") in the deliberations. ${ }^{47}$

All Acts on Federal courts contain identical provisions on law clerks (or court clerks, as they are referred to in the English translations of these Acts), which provide, as in the example of the Federal Act on the Federal Patent Court: ${ }^{48}$

1 Court clerks take part in case briefings and in making decisions. They act in an advisory capacity.

2 They draft proposals under the supervision of a judge and edit the decisions of the Federal Patent Court.

Given that the time-consuming task of writing judgments mainly lies with the law clerks, and not the judges, Swiss courts often employ more law clerks than judges. While there are currently 57 judges at the Federal Supreme Court, the same court employs 141 law clerks. ${ }^{49} 122$ of them are admitted to the bar, 49 of them hold a doctorate and three are professors of law.

In some Cantons, law clerks are even allowed to act in place of judges in some respects, for instance in matters of urgency. ${ }^{50}$ In the Canton of Basel-Landschaft, for example, some law clerks at the Court of Appeal are empowered to grant provisional measures in lieu of judges. In the Canton of Valais/Wallis, law clerks may substitute district court judges. ${ }^{51}$

In New Zealand, law clerks, or judges' clerks, as they are sometimes referred to, ${ }^{52}$ have a different role, one often described as "research assistant". ${ }^{53}$ Rather than working

\footnotetext{
${ }^{47}$ See $X v$ Canton of Thurgau [2007] BGE 134 I 16 (Federal Supreme Court) at 19.

${ }^{48}$ Bundesgesetz über das Bundespatentgericht 2009, art 24 (translation: Federal Act on the Federal Patent Court) as per the semi-official translation on <www.admin.ch/opc/en/classifiedcompilation/20071763/index.html>; see also Bundesgesetz über das Bundesgericht 2005, art 24 (translation: Federal Act on the Federal Supreme Court); Bundesgesetz über das Bundesverwaltungsgericht 2005, art 26 (translation: Federal Act on the Federal Administrative Court); Bundesgesetz über die Organisation der Strafbehörden des Bundes 2010, art 59 (translation: Federal Act on the Organisation of the Federal Criminal Justice Authorities).

49 See Federal Supreme Court "Richter und Personal" <www.bger.ch/index/federal/federal-inherittemplate/federal-richter.htm> (translation: "Judges and personnel").

${ }^{50}$ Heimgartner, above $\mathrm{n} 44$, at 302 .

${ }^{51}$ At 302.

${ }^{52}$ Thomas Gibbons “The rise of Judges' Clerks" [2002] NZLJ 136 at 136.
} 
for the court in general and being assigned to cases, they are assigned to one particular judge (or, in case of inferior courts, to some judges). Their task is, in principle, not to write the judgments but to carry out the research for the judges in order to enable them to write their judgments. Nevertheless, some authors believe that New Zealand law clerks play a larger role than is sometimes admitted. ${ }^{54}$

\section{B. Who appoints the judges?}

\section{Who appoints the judges in New Zealand?}

In New Zealand, the appointment procedures are governed by constitutional conventions rather than statutory law. ${ }^{55}$ The Attorney-General who is for the most part responsible for the appointments enjoys therefore a certain freedom to design the procedure. Accordingly, different Attorney-Generals have adopted different procedures. ${ }^{56}$

The procedures to appoint District Court Judges and High Court Judges are, while not identical in every respect, by and large very similar. They both consist of four phases: First, prospective candidates submit expressions of interest either of their own or upon public advertisements or upon specific invitation after wide consultation. Second, a longlist is produced and submitted to the Attorney-General. Third, the Attorney-General, after such consultation as deemed necessary and, when appointing High Court Judges, with the agreement of the Chief Justice, decides who is to be on the shortlist for interviews. Fourth, after the interviews and reputation checks, the Attorney-General selects a candidate, mentions the appointment in Cabinet and tenders formal advice to the Governor-General. ${ }^{57}$

In both appointment procedures, the legal establishment is consulted before the appointment: For High Court Judges, the Solicitor-General, before producing the longlist,

\footnotetext{
${ }^{53}$ At 136.

${ }^{54}$ At 136.

${ }^{55}$ Law Commission Review of the Judicature Act 1908: Towards a new Courts Act (R126 2012) at [5.10][5.15].

${ }^{56}$ John McGrath “Appointing the Judiciary” [1998] The New Zealand Law Journal 314 at 314.

${ }^{57}$ See Ministry of Justice Judicial Appointments: Office of District Court Judge (2012) at 6; Crown Law Office Judicial Appointments Protocol (Crown Law Office, 2014) at 4-5.
} 
consults with senior judges ${ }^{58}$ for District Court Judges, the President of the Law Society is consulted. ${ }^{59}$

Formally, the power to appoint the judges in New Zealand is vested in the GovernorGeneral $^{60}$ who by convention acts on advise of the Attorney-General ${ }^{61}$ (or, in some cases, of the Prime Minister ${ }^{62}$ or the Minister of Maori Affairs ${ }^{63}$ ). De facto however, it is not the Governor-General but the advisor (that is, apart from the noted exceptions, the AttorneyGeneral) who takes the decision.

Appointments to the Court of Appeal and the Supreme Court occur typically through judicial promotion from the High Court and the Court of Appeal. ${ }^{64}$

\section{Who appoints the judges in Switzerland?}

In the Swiss Federation there is a similar, though not identical, disparity between who selects the candidates to be appointed and who finally appoints them. While the Federal Assembly elects all Federal court judges ${ }^{65}$, the elections are prepared by the Judiciary Committee $^{66}$ (Gerichtskommission, Commission judiciaire, Commissione giudiziaria, Cumissiun giudiziala), which usually selects one of the candidates and advises the

\footnotetext{
${ }^{58}$ Crown Law Office, above n 57, at 4.

${ }^{59}$ Ministry of Justice, above $\mathrm{n} 57$, at 6.

${ }^{60}$ See Judicature Act 1908 s 4(2) and 57(2); Supreme Court Act 2003 s 17(1)(b).

${ }^{61}$ Law Commission, above n 55, at [512-513]; Philip A Joseph "Appointment, discipline and removal of judges in New Zealand" in HP Lee (ed) Judiciaries in Comparative Perspective (Cambridge University Press, Cambridge, 2011) 66 at 67.

${ }^{62}$ Appointment of the Chief Justice: see Law Commission, above $n$ 55, at [5.11].

${ }^{63}$ Appointment of the judges of the Maori Land Court: see Joseph, above n 61, at 67-68.

${ }^{64}$ Joseph, above n 61, at 69.

${ }^{65}$ Bundesgesetz über das Bundesgericht 2005, art 5(1) (translation: Federal Act on the Federal Supreme Court); Bundesgesetz über das Bundesverwaltungsgericht 2005, art 5(1) (translation: Federal Act on the Federal Administrative Court); Bundesgesetz über das Bundespatentgericht 2009, art 9(1) (translation: Federal Act on the Federal Patent Court); Bundesgesetz über die Organisation der Strafbehörden des Bundes 2010, art 42(1) (translation: Federal Act on the Organisation of the Federal Criminal Justice Authorities).

${ }^{66}$ See Bundesgesetz über die Bundesversammlung 2002, art 40a (translation: Federal Act on the Federal Assembly) as per the semi-official translation on <http://www.admin.ch/opc/en/classifiedcompilation/20010664/index.html>.
} 
Federal Assembly to elect this candidate. ${ }^{67}$ The Judiciary Committee is a select committee of the Federal Assembly and accordingly comprises members of both chambers of parliament. Pursuant to art 40a(5) of the Bundesgesetz über die Bundesversammlung $^{68}$, each parliamentary group ${ }^{69}$ has the right to at least one seat on the Committee. Of the 17 members of the Committee, 5 are Councillors of States and 12 are National Councillors.

The Federal Assembly has so far never refused to elect the candidate chosen by the commission.

The Federal Supreme Court was established as the Supreme Court of Switzerland in 1849 in the first Swiss Federal Constitution 1848. Article 96 thereof provided that the members of the Federal Supreme Court are elected by the Federal Assembly. When the Swiss Federal Constitution 1848 was revised entirely and replaced by the Swiss Federal Constitution 1874, this provision was adopted without change in art 107(1) of the new constitution.

The Swiss Federal Constitution was revised entirely for the second time in the 1990s and replaced by the Swiss Federal Constitution 1999. No changes were made to the procedure of appointment of the judges of the Federal Supreme Court: Article 168(1) states that they are elected by the Federal Assembly. The rationale of this system mentioned in the travaux préparatoires is what presumably was the original reason for establishing it in the $19^{\text {th }}$ century: The Federal Assembly has always been perceived as the supreme federal authority (subject to the rights of the people and the cantons) ${ }^{70}$ and was therefore appointed to elect all the other highest federal authorities. ${ }^{71}$

\footnotetext{
${ }^{67}$ Bundesgesetz über die Bundesversammlung 2002, art 40a(1)-(3) (translation: Federal Act on the Federal Assembly).

${ }^{68}$ Bundesgesetz über die Bundesversammlung 2002 (translation: Federal Act on the Federal Assembly).

${ }^{69}$ Parliamentary groups are composed of the Councillors of one party. A parliamentary group must consist of a minimum of five members. Members of smaller parties may form their own parliamentary groups or join a bigger party's group.

70 See Bundesverfassung der Schweizerischen Eidgenossenschaft 1999, art 148(1) (translation: Federal Constitution of the Swiss Confederation).

${ }^{71}$ Bundesrat Botschaft über eine neue Bundesverfassung (BBl 1997 1) at 395 (translation: Federal Council Report on a new Federal Constitution).
} 
When in Switzerland several new federal courts were established, the Federal Council first proposed to appoint the required judges. ${ }^{72}$ In a statement, the Federal Supreme Court, noting that the new federal courts were to review acts by the Federal administration, for which ultimately the Federal Council was responsible, criticised this proposal in no uncertain terms: "Die Wahl durch den Bundesrat ist verfassungsrechtlich bedenklich und daher abzulehnen."73 ("The election by the Federal Council is questionable under constitutional law and should be rejected"). The law commission of the Council of States agreed with the Federal Supreme Court. ${ }^{74}$

Two reasons were crucial for having the parliament appoint the judges instead of the government: The first one, which was mentioned by the Federal Supreme Court, is the separation of powers, which might be in danger if the judges were to review acts of those who are in charge of re-electing them. While this reason was certainly important in the recent debate, it does not explain why judges at courts that are not competent to perform such review are nevertheless not appointed by the government either. The second reason is therefore even more important; it is one deeply rooted in the Swiss concept of the state: As the judiciary is a power separate from the legislative and the government, its authority must be underpinned by what is called "demokratische Legitimation" (democratic legitimacy). ${ }^{75}$ The authority of any public official depends on the degree of their democratic legitimacy, which is strongest where an official is elected by the people. An official's democratic legitimacy is weakened when the appointment was made by the parliament (and thus indirectly by the people) and it is perceived as even weaker when the official is appointed by the government. This point is illustrated by Councillor Schmid's statement in the course of the recent debate that if the new federal courts were

\footnotetext{
72 Bundesamt für Justiz Funktion der Gerichtskommission der Vereinigten Bundesversammlung Vorbereitung von Richterwahlen (VPB (2003) 69.3) at ch I2.a (translation: Federal Office of Justice Function of the Justice Commission of the Federal Assembly Preparation of Elections of Judges).

${ }^{73}$ Bundesgericht Stellungnahme des Bundesgerichts vom 23. Februar 2001 (BBl 2001 5890) at 5892-5893 (translation: Federal Supreme Court Statement of the Federal Supreme Court of 23 February 2001).

${ }^{74}$ Bundesamt für Justiz, above n 72, at ch I2.b.

75 Regina Kiener "Richterwahlen in der Schweiz" [2002] 71 Betrifft JUSTIZ 378 at 378 (translation: "Elections of Judges in Switzerland")
} 
supposed to be real courts, then, pursuant to the rationale of the Swiss concept of state, the judges had to be elected by the people or the parliament, not the government. ${ }^{76}$

A different light was shed on the issue in 2001 by Councillor Schmid during a parliamentary debate on the introduction of a justice appointment board. Councillor Schmid stated that supreme court judges should not be appointed purely based on expertise because they were not apolitical robots but instead shaped actively the politics to the highest extent. ${ }^{77} \mathrm{He}$ feared that an appointment board would always choose judges with a preference of constitutional rights over democratic rights. ${ }^{78}$ In other words, he was afraid of what is in New Zealand referred to as judicial activism. While this fear of judicial activism was not the original reason for having the parliament elect the federal judges at the time the Federal Supreme Court was established, it is now presumably one of the main reasons for upholding the system.

In New Zealand, that very same fear is perceived as a possible root of overpoliticization of the appointment process. ${ }^{79}$

In the Cantons, usually a distinction is made between the judges at the lower courts and the courts of appeal. The most common system provides that court of appeal judges are elected by the parliament, whereas the lower court judges are elected by the people of their district of jurisdiction. However, there are still eight Cantons where even the judges of the higher courts are elected by the people.

The judges at courts of first instance are in most Cantons elected by the people. ${ }^{80}$ Exceptions include the Cantons of Ticino, Nidwalden, Schaffhausen, Lucerne and Bern, where the parliament elects all the judges of the Canton. The Canton of Bern adopted this rule only recently in a law reform of 2009.

\footnotetext{
${ }^{76}$ Carlo Schmid (6 December 2001) Amtliches Bulletin des Ständerates at 910 (translation: Official Protocol of the debates of the Council of States).

${ }^{77}$ At 911.

${ }^{78}$ At 911.

${ }^{79}$ See James Allan "Judicial Appointments in New Zealand: if it were done when 'tis done, then 'twere well it were done openly and directly" in Kate Malleson and Peter H Russell (eds) Appointing Judges in an Age of Judicial Power: Critical Perspectives from around the World (University of Toronto Press, Toronto, 2006) 103 at $109-110$.

${ }^{80}$ Kiener, above n 75 , at 378 .
} 
The procedures followed in the Cantons resemble the Federal course of action as far as appointments by the parliaments are concerned. In contrast, the same can of course not be said of elections by the people. Those are typically controlled by the parties. Often the parties will prior to the election confer with each other and distribute the vacancies among the parties according to their electoral share. In the Canton of Zurich for instance this is a task of the Interparteiliche Konferenz ("inter-party conference"), which also examines the candidates' suitability and then publishes an "official" proposal of candidates. Contested elections occur therefore only rarely, when the parties are unable to come to an agreement or when a political outsider challenges the official candidates.

Where the judges are elected by the people, the parties are naturally strongly involved. Unless candidates are supported by a party, they will find it very difficult to raise enough attention and to be sufficiently well-known to the electorate. The information on the candidates given to the public is usually scarce: Typically, it merely includes the candidate's age, civil status, education and professional career. With few exceptions, there are no campaigns for or against judges. ${ }^{81}$

As mentioned above, the judges, through their election by the people or the parliament, enjoy a higher authority, or democratic legitimacy as it were, than they would if they were appointed by the government.

Presumably for the same reason it is in New Zealand the Governor-General, the official representative of the Crown in New Zealand, who finally makes the appointment, and not the Attorney-General who, while de facto being in charge of the decision, formally only tenders advice to the Governor-General. An appointment by the GovernorGeneral and thus by the Crown itself must give a judge a higher standing than the appointment by a government officer would.

\section{By which criteria are judges selected?}

The criteria by which judges are selected are typically not stated in legislation. This is true both for New Zealand and Switzerland, and in particular for Swiss Federal court

\footnotetext{
${ }_{81}$ But see, for an exception, the case of Klee v Liberal-Democratic Party of the District of Werdenberg [1976] 102 Ia BGE/ATF 264, where a judge who was not re-elected complained about a pamphlet that criticised him harshly.
} 
judges. Nevertheless, the criteria are no secret. In its 2006 report, the Judiciary Committee informed about the criteria applied in appointing the Federal Administrative Court judges. It explained that the first and most important criterion was the professional expertise of the candidates, the second criterion the adequate representation of the official languages and the third the political attitude of the candidates. ${ }^{82}$

This is however somewhat misleading when it comes to the criterion of the political attitude of a particular candidate. While it certainly is not the sole criterion applied by the Judiciary Committee and the Federal Assembly, it is still of paramount importance: There has not been elected a politically independent Federal Supreme Court judge since Logoz J in $1942 .^{83}$

Currently, there are 57 judges at the Federal Supreme Court, 19 of them in a part-time job. Of the 38 full-time judges, three are Italian-speaking, twelve French-speaking and 23 German-speaking. Given that about $23 \%$ of the Swiss population is French-speaking and about $6 \%$ Italian-speaking, the distribution of the languages seems adequate. ${ }^{84}$

As most of the Cantons are monolingual (the exceptions being the four Cantons of Bern/Berne, Fribourg/Freiburg, Wallis/Valais and Graubünden/Grigioni/Grischun), the language is rarely a criterion for judges at the courts of the Cantons. As far as the judges are elected by the parliaments, this leaves the candidates' professional expertise and their political attitude as determinant factors. Where the judges are elected by the people, the criteria applied by each individual must of course remain obscure.

In New Zealand, too, the criteria of appointment are nowadays well known even though they are not stated in legislation. The Law Commission published in 2012 a comprehensive report on New Zealand's present system of judicial appointments, in

\footnotetext{
${ }^{82}$ Gerichtskommission Vorbereitung der Wahlen an das Bundesverwaltungsgericht (2006) at 4 (translation: Judiciary Committee Preparation of the elections of the Federal Administrative Court Judges) <www.parlament.ch/d/organe-mitglieder/kommissionen/weitere-kommissionen/ gerichtskommission/ Documents/gk-rueckblick-2011-2013-d.pdf>.

${ }^{83}$ Markus Felber "Problematische Kür der Richter in der Schweiz" Neue Zürcher Zeitung (31 December 2009) at 11 (translation: Troublesome election of judges in Switzerland).

${ }^{84}$ Only $0.7 \%$ of the Swiss population are Romansh-speaking. So far, two Federal Supreme Court judges have been Romansh-speaking and one decision of the Federal Supreme Court has been rendered in Romansh (Corporaziun da vaschins da Scuol v Regenza dal chantun Grischun [1996] 122 I BGE/ATF 93).
} 
which it recommended enacting statutory criteria. ${ }^{85}$ The then Minister of Justice however did not support said recommendation. Instead, she proposed to require the AttorneyGeneral "to produce public guidelines or protocols outlining the process to be followed when he or she solicits and advances judicial appointment recommendations to the Governor-General". ${ }^{86}$ The Attorney-General agreed with this proposal and published two booklets setting out the process for appointing judges of District Courts and Higher Courts. ${ }^{87}$

While the proceedings for appointments of District Court judges and Higher Court judges may differ, the candidates are assessed based on largely identical sets of criteria, which cover four categories: legal ability, qualities of character, personal technical skills and reflection of society. ${ }^{88}$

Legal ability includes a sound knowledge of the law and experience of its application. The candidate must have demonstrated overall excellence as a lawyer in a relevant legal occupation. ${ }^{89}$ Qualities of character sought are, among others, personal honesty and integrity, open mindedness and impartiality, social sensitivity, common sense and the ability to work hard..$^{90}$ Certain personal technical skills are deemed important, which comprise, inter alia, effective communication with both lay people and lawyers, the ability to deal with complex material and organisational skills. ${ }^{91}$ In terms of reflection of society judges are expected to be aware of, and sensitive to, the diversity of modern New Zealand society (including tikanga Māori and Te Reo), have experience of the community of which the court is part and demonstrate their social awareness. ${ }^{92}$

All these criteria are included to assess a candidate's suitability to be a judge. Clearly, this catalogue of criteria is the result of considerable efforts to determine the qualities that

\footnotetext{
${ }^{85}$ Law Commission, above n 55, at 57.

${ }^{86}$ Office of the Minister of Justice Government response to the Law Commission's report "Review of the Judicature Act 1908: towards a new Courts Act" (2013) at [31].

${ }^{87}$ Ministry of Justice, above n 57; Crown Law Office, above n 57.

${ }^{88}$ See Crown Law Office, above n 57, at 3-4; Ministry of Justice, above n 57, at 5.

${ }^{89}$ See Crown Law Office, above n 57, at 3-4; Ministry of Justice, above n 57, at 5.

90 See Crown Law Office, above n 57, at 4; Ministry of Justice, above n 57, at 5.

${ }^{91}$ See Crown Law Office, above n 57, at 4; Ministry of Justice, above n 57, at 5.

92 See Crown Law Office, above n 57, at 4; Ministry of Justice, above n 57, at 5.
} 
a good judge should have. It is equally clear that all the actors involved in the appointment process have the ambition to seek out the best possible candidate.

This is not the case in Switzerland, where there is no evidence that the authorities preparing or making judicial appointments have made sufficient effort to determine the necessary qualities of a judge.

\section{The take on appointment boards}

Introducing appointment boards was recently discussed in both jurisdictions. When in Switzerland several new federal courts were established, the Federal Council first proposed to appoint the judges because it found that the Federal Assembly were hardly capable to evaluate and appoint the required number of roughly 100 judges. ${ }^{93}$ The law commission of the Council of States rejected this unanimously because of concerns with the separation of powers. It instead suggested establishing a justice commission as an extra-parliamentary body comprising legal scholars, judges and barristers, which would submit proposals to the Federal Assembly. ${ }^{94}$

In the parliamentary debate in the Council of States however the Councillors preferred establishing a parliamentary justice commission instead, approving a motion of Councillor Schmid. ${ }^{95}$ Schmid argued that the proposals of an extra-parliamentary body would have too much weight due to that body's expertise. The Federal Assembly would be hard pressed not to follow the proposals. ${ }^{96}$ Given that supreme court judges actively shaped politics, the appointment needed to be at the discretion of the Federal Assembly. ${ }^{97}$ Fellow Councillor Schiesser added that the Federal Assembly should be both factually and legally accountable for the appointments, which it would not be if the candidates were evaluated by an extra-parliamentary body. ${ }^{98}$ Thus, the parliament subsequently installed a new parliamentary commission, the Judiciary Committee.

\footnotetext{
${ }^{93}$ Bundesamt für Justiz, above $\mathrm{n}$ 72, at ch I2.a.

${ }^{94}$ At ch I2.b.

${ }^{95}$ See Schmid, above $\mathrm{n} 76$, at 910-912.

${ }^{96}$ Bundesamt für Justiz, above $\mathrm{n} 72$, at ch I2.c.

${ }^{97}$ Schmid, above $\mathrm{n} 76$, at 911.

${ }^{98}$ Fritz Schiesser (6 December 2001) Amtliches Bulletin des Ständerates at 914 (translation: Official Protocol of the debates of the Council of States).
} 
Similar to the Federation, the Cantons have almost unanimously rejected the idea of appointment boards. However, two French-speaking Cantons have adopted institutions that come close to appointment boards: In the bilingual Canton of Fribourg/Freiburg, a Justice Council ("Justizrat"/“Conseil de la magistrature") was established, which is composed of nine members: one member each of the parliament and the government, two judges, one professor of the local university, one public prosecutor, one attorney and two members to be proposed by the Council itself. One of the tasks of the Council is to prepare judicial appointments: It will, inter alia, assess all the candidates and report to the parliament, which then elects the judges. ${ }^{99}$

The Conseil supérieur de la magistrature ${ }^{100}$ of the Canton of Geneva, which consists mainly of members of the judiciary and the legal profession, has similar functions. It prepares judicial appointments by reporting on its evaluation of the candidates' expertise. ${ }^{101}$ Nevertheless, the bottom line is that neither the Federation nor any of the Cantons have granted the power to appoint judges to an appointment board.

New Zealand, too, has recently discussed and rejected the idea of establishing a judicial appointment board, for reasons that are not entirely different from those in Switzerland. One of the main concerns that were expressed in the discussion was that accountability would be diffused and thus shifted away from the one responsible for the appointment. ${ }^{102}$ This, however, is also where the similarities end. In New Zealand it was criticised that such a board might end up enabling rather than eliminating political influence on appointments due to its members being selected in a political process ${ }^{103}$ or due to the Attorney-General being able to choose for political reasons between the candidates approved by the board. ${ }^{104}$

\footnotetext{
${ }^{99}$ Loi sur la justice du canton de Fribourg 2010/Justizgesetz des Kantons Freiburg 2010, art 12 (translation: Act on the judiciary of the Canton of Fribourg).

${ }^{100}$ Translation: Supreme Council of the Judicial Magistrature.

${ }^{101}$ Constitution de la République et canton de Genève 2012, art 127 (translation: Constitution of the Republic and Canton of Geneva).

${ }^{102}$ See Geoffrey Palmer “Judicial Selection and Accountability: Can the New Zealand System Survive?” in B D Gray and R B McClintock (eds) Courts and Policy: Checking the Balance (Brooker's, Wellington, 1995) 11 at 82-83; Allan, above $n$ 79, at 116.

${ }^{103}$ Palmer, above $\mathrm{n} 102$, at 82.

${ }^{104}$ Allan, above n 79, at 116.
} 
There is, in this author's opinion, some truth to these arguments. If one assumes for the sake of argument that there is something wrong with a member of government appointing the judges, then how would that be remedied by an appointment board? Installing an appointment board will only shift the issue from "who appoints the judges?" to "who appoints those who appoint the judges?" without substantially altering the issue. At the same time, the accountability of the Attorney-General would partly be shifted to the appointment board. Being able to choose from candidates cleared by the board, the Attorney-General would presumably enjoy a considerable freedom in selecting a preferred candidate for inappropriate reasons.

It is submitted that appointment boards make sense where they tender advice because those appointing the judges are in need of said advice for lack of relevant experience. This is the case in Switzerland. Another scenario where appointment boards may be a sensible choice is where they make the appointments themselves. Certainly, the advantages and disadvantages of this scenario are inevitably highly dependent on how the board is composed and how its members are appointed. Nevertheless, there is something to be said for the view that, if composed prudently, they may be more representative of the society and more visibly politically neutral or neutralised.

\section{E. The take on political influence}

In Switzerland, on the other hand, the prevailing fear was that installing an appointment board would diminish political influence. Switzerland openly embraces a highly politicised appointment procedure.

The appointments are prepared by the Judiciary Committee, which is composed of members of both chambers of the Federal Assembly. Both the Committee and the Federal Assembly aim at the political parties being represented at the Federal Supreme Court according to their electoral share. In case of a vacancy at a federal court, the Committee publishes job advertisements in the major newspapers and informs the political parties. ${ }^{105}$ The Committee then reviews the applicants. It must take into account the applicants'

\footnotetext{
$\overline{105}$ Bundesgesetz über die Bundesversammlung 2002 (translation: Federal Act on the Federal Assembly), art 40a(2).
} 
professional expertise as well as social and political aspects. ${ }^{106}$ It will usually select one of the candidates and present its proposal to the political parties. Having regard to their feedback, the Committee then submits its recommendation to the Federal Assembly. While the Committee used to present more than one candidate in politically controversial cases, it changed the practice around 2012 and started to strictly recommend only one candidate to the Federal Assembly. ${ }^{107}$ Occasionally, this leads to contested elections when one party nevertheless puts up a candidate of its own.

Before the Judiciary Committtee was established, sometimes candidates that were nominated by a party were not elected due to concerns on their qualifications, even if their party was underrepresented in the court at the time. When the Federal Administrative Court was established, the Federal Assembly had to appoint 72 new judges. The largest political party, the SVP, apparently failed to generate enough sufficiently qualified candidates. Therefore, the SVP was underrepresented compared to its electoral share by at least six judges. ${ }^{108}$ The SVP accepted this result for the time being. Along the same lines, the Federal Assembly elected on 21 December 2011 a female candidate as a judge of the Federal Administrative Court even though the Committee had noted in its report that she was a member of a party that was already slightly overrepresented. The Committee however found her to be the most suitable candidate. $^{109}$

However, while the Judiciary Committee and the Federal Assembly do put emphasis on the candidates' qualifications, the membership in one of the major political parties remains almost a prerequisite to being elected as a federal judge: At the Federal Supreme Court, there has not been a politically independent judge since 1953, when Logoz J

\footnotetext{
${ }^{106}$ Bundesamt für Justiz (translation: Federal Office of Justice), above $\mathrm{n}$ 72, at ch II1.

107 Sekretariat der Gerichtskommission Die Gerichtskommission der Vereinigten Bundesversammlung während der ersten Hälfte der 49 Legislaturperiode, 2011 - 2013 (2013) at 3 <www.parlament.ch/d/organe-mitglieder/kommissionen/weitere-kommissionen/gerichtskommission/ Documents/gk-rueckblick-2011-2013-d.pdf> (translation: Secretary of the Judiciary Committee The Judiciary Committee during the first half of the 49th legislative term 2011-2013).

${ }^{108}$ See Gerichtskommission, above $\mathrm{n}$ 82, at 10.

${ }^{109}$ Gerichtskommission Bericht der Gerichtskommission vom 8 Dezember 2011 (11.210 b) at 2 <www. parlament.ch/sites/kb/2012/Kommissionsbericht_GK_12.200_2012-03-07.pdf> (translation: Judiciary Committee Report of the Judiciary Committee of 8 December 2011).
} 
retired. 50 of the 72 judges at the Federal Administrative Court and all 38 full-time judges of the Supreme Court are members of a political party. Only seven Federal Administrative Court judges had declared to be neither a member nor a sympathiser of a party. ${ }^{110}$ The reports issued by the Judiciary Committee to the Federal Assembly suggest that the Committee usually first determines which linguistic region the judge should be from and which party is entitled to have one of its members appointed. Then, the Committee will focus on the applicants that meet these requirements and nominate the one that it perceives best suited. Aside from the candidates' expertise the Committee will also take into account the gender, as women are still underrepresented at all federal courts. Therefore, while a candidate's merit is an important - according to the Committee the most important ${ }^{111}$ — criterion, it remains only one of several criteria.

In New Zealand, in contrast, the appointment procedure is tailored to minimise political influences and to provide for appointments based entirely on merit. ${ }^{112}$ The procedure is mainly in the hands of the Attorney-General who must by convention act irrespective of political influences. Candidates are not discussed in Cabinet. ${ }^{113}$

It is somewhat puzzling to an outsider such as this author that the power to decide whom to appoint, which by constitutional convention must be a decision free of any political considerations, ${ }^{114}$ is vested in a political actor who is appointed by the head of government, presumably following political considerations. The role of the AttorneyGeneral is, however, two-fold in that he or she is both a minister and the chief law officer of the Crown. Judicial appointments are made in the latter role. ${ }^{115}$ It appears that past Attorneys-General were fully aware of their responsibility and honoured their obligation to make appointments irrespective of party political considerations. ${ }^{116}$

\footnotetext{
${ }^{110}$ Gerichtskommission, above $\mathrm{n} 82$, at 10.

${ }^{111}$ Hans Hess (25 September 2013) Amtliches Bulletin der Vereinigten Bundesversammlung at 1784 (translation: Official Protocol of the debates of the Federal Assembly) (stating that the fair representation of the political parties was the second most important criterion).

${ }^{112}$ See McGrath, above n 56, at 315.

113 Joseph, above n 61, at 67.

114 Ministry of Justice Appointing Judges: A Judicial Appointments Commission for New Zealand? (Ministry of Justice, Wellington, 2004) at 18.

115 Joseph, above n 61, at 67.

${ }^{116}$ See McGrath, above n 56, at 316; Palmer, above n 102, at 44.
} 
However, even in the New Zealand system, where political influences are minimised as far as possible, it is recognised that, while party politics may be eliminated, to some degree politics in a wider sense are always a part of the process. ${ }^{117}$ The former President of the Court of Appeal stated: ${ }^{118}$

Appointments by the executive are inevitably political to a greater or less degree. Among candidates of roughly equal standing a Government must naturally be disposed to select one whose sympathies are thought to be congenial to its policies. Probably the more senior the judicial office, the more significant the political or philosophical factors.

This is, in this author's view, true not only of Governments but of any person who is given the power to appoint judges. If the term "policies" is framed wide enough such as to include for instance having "a broad view of and interest in society" 119 or being "aware of and sensitive to the diversity of modern New Zealand society" ${ }^{120}$, then it becomes obvious that a candidate's worldview is an element that is rightly considered in the course of the examination. Lawyers holding politically extremist views-for instance a racist or radical islamist - would hardly be deemed suitable for the bench.

And this author ventures to suggest that considering a candidate's worldview is nothing to be frowned upon. While it is true that the judiciary does not necessarily need to be representative, ${ }^{121}$ public confidence might be enhanced not only by diversity but also by a certain amount of what could be referred to as "macro-political representativity". Diversity in cultural or gender-related terms is important in terms of "justice seen to be done" 122 because it counteracts perceptions of the judiciary as a "selfperpetuating oligarchy"123. The same holds true, albeit to a lesser extent, for macropolitical representativity. Such representativity has another benefit though, because it promotes a balanced composition of the courts. People's political preferences are the expression of their view of how the society should be shaped and, accordingly, their

\footnotetext{
117 See Palmer, above n 102, at 47.

118 Robin Cooke "Empowerment and Accountability: The Quest for Administrative Justice" (1992) 18 Commonwealth Law Bulletin 1326 at 1331.

119 Palmer, above n 102, at 47.

120 McGrath, above n 56, at 315.

121 Palmer, above n 102, at 41.

${ }^{122}$ See $R v$ Sussex Justices, ex parte McCarthy [1924] 1 KB 256 (CA) at 259.

${ }^{123}$ Palmer, above n 102, at 82.
} 
attitude towards developments in society. And these views, it is submitted, inform to some extent their judicial decisions.

The initial appointments to the New Zealand Supreme Court are perceived as evidence of the system working (meaning that the risk of being held accountable led the Attorney-General to do the right thing). ${ }^{124}$ Due to the Supreme Court being a newly established court, four Supreme Court judges needed to be appointed at the same time. The course of action most coherent with the New Zealand system was simply promoting the four most senior existing Court of Appeal judges. Indeed, according to Allan, this was what "many considered to be the only constitutionally proper [course of action]". ${ }^{25}$ The Attorney-General however had first refused to promise that she would do that, claiming complete discretion instead. It was only after much backtracking due to political and grassroots opposition that she eventually confirmed to and then in fact did appoint the four most senior Court of Appeal judges. ${ }^{126}$

These appointments were however unusual in just about every relevant aspect. This starts with the legal situation at the outset: At the time, there was arguably only one constitutionally correct way to handle the issue. Therefore, whether the appointments were made properly could be judged by the result. Somewhat ironically, critics of the Court would later doubt whether it was smart to "promote everybody en masse from the Court of Appeal". ${ }^{127}$

The second unusual point was the high profile character of the appointments due to their significance concerning the highest court of the land. It is difficult to imagine that a threatening opposition could be mobilised when only a District Court appointment was at stake.

The third unusual point was the transparency created by the Attorney-General when she stated her intentions concerning the appointments. This alone made opposition possible in the first place.

\footnotetext{
${ }^{124}$ See Allan, above n 79, at 117.

125 At 107.

${ }^{126}$ At 107.

127 Phil Taylor "Justice in the firing line" New Zealand Herald (5 May 2012) <http://www.nzherald.co.nz/nz/news/article.cfm?c_id=1\&objectid=10803600>.
} 
In contrast, with any other judicial appointment, the Attorney-General will not make anything public about why one candidate was preferred over another - the public will actually never know about any other candidate who was not preferred. Essentially, the public is left with naught but a name and the Attorney-General's word it's the best one. This leaves little room for accountability, as the accountability of a decision in cases where decision-making cannot be judged by its outcome (because the outcome cannot be determined to be right or wrong) is contingent on transparency.

\section{Discipline and removal from office of judges}

\section{A. Term of office and re-election of Swiss judges}

New Zealand and Switzerland differ in a fundamental way: Unlike New Zealand judges, Swiss judges (with the exception of the judges in the Canton of Fribourg/Freiburg) do not have tenure. They are elected for a specific term of office instead. The term of office of all Federal court judges amounts to six years. Re-elections are permissible. Judges leave office at the end of the year in which they reach 68 years of age. ${ }^{128}$

Re-election of federal court judges is usually a formality. For more than 100 years reelection was only refused to judges based on the convention that they should leave office when they turn 70 . However, in the last 25 years political attempts to put pressure on judges have become more frequent. ${ }^{129}$ This development came down to a judge of the Federal Supreme Court, Martin Schubarth, being refused re-election in 1990. This was then referred to as an "accident" - the intention had been "merely" to teach Schubarth J a lesson. ${ }^{130}$ Commentators noted that, while the Federal Supreme Court had rendered some politically controversial decisions in that year (inter alia forcing the last Canton to grant

\footnotetext{
128 Bundesgesetz über das Bundesgericht 2005 (translation: Federal Act on the Federal Supreme Court), art 9(1)-(2).

129 See Niccolo Raselli "Richterliche Unabhängigkeit" (2011) 3 Justice - Justiz - Giustizia at n 15 <www.richterzeitung.ch> (translation: "Judicial independence").

130 At n 15.
} 
women the right to vote ${ }^{131}$ and banning crucifixes from class rooms ${ }^{132}$ ), Schubarth $\mathrm{J}$ had not been involved in any of these decisions. ${ }^{133}$

After much public criticism, the Federal Assembly re-elected Schubarth J a week later. The complaints against Schubarth $\mathrm{J}$ had been investigated by a parliamentary working group (the predecessor of the Judiciary Committee) and found not grave enough to justify denial of re-election. The working group acknowledged Schubarth J's high level of expertise and noted that the quality of his work had not given reason to any complaints. ${ }^{134}$

The Judiciary Committee recognized that the Federal Assembly should only refuse to re-elect a judge in cases where the requirements for the removal of the judge are met. Thus, in its Handlungsgrundsätze zum Verfahren der Kommission im Hinblick auf eine Amtsenthebung oder eine Nichtwiederwahl ${ }^{135}$ published in 2011, it stated that the procedural rules on removing a judge apply analogously in cases of refusal of reelection. $^{136}$

The same or similar rules apply in most Cantons, even though the length of the term of office varies. The winner in this regard is the Canton of Ticino with 10 years. ${ }^{137}$ The lone exception, as noted above, is the Canton of Fribourg/Freiburg, where the pertinent act, the law on the judiciary, provides that judges are elected for an indefinite period of time. ${ }^{138}$ This was an innovation introduced by the new Constitution in 2004. ${ }^{139}$ Judges

${ }^{131}$ Rohner v Canton of Appenzell Innerrhoden [1990] 116 Ia BGE/ATF 359.

${ }^{132}$ Municipality of Cadro v Bernasconi [1990] 116 Ia BGE/ATF 252.

${ }^{133}$ Kurt Bruggisser "Zur Abwahl von Martin Schubarth” Neue Zürcher Zeitung (Zurich, 6 December 1990) at 21 (translation: "On the de-selection of Martin Schubarth").

134 Theo Fischer (12 December 1990) Amtliches Bulletin der Vereinigten Bundesversammlung at 2523 (translation: Official Protocol of the debates of the Federal Assembly).

135 Translation: Principles of action for the Committee's procedure regarding removal or refusal of reelection.

${ }^{136}$ Handlungsgrundsätze der Gerichtskommission zum Verfahren der Kommission im Hinblick auf eine Amtsenthebung oder eine Nichtwiederwahl 2011, art 15(1) (translation: Principles of action of the Judiciary Committee for the Committee's procedure regarding removal or refusal of re-election).

137 Costituzione della Repubblica e Cantone Ticino 1997, art 81(1) (translation: Constitution of the Republic and Canton of Ticino).

138 Loi sur la justice du canton de Fribourg 2010/Justizgesetz des Kantons Freiburg 2010, art 6(1) (translation: Act on the judiciary of the Canton of Fribourg). 
may only be removed from office in case of misconduct or incapability, if they cease to meet the requirements to be elected, or if they breach their duty to be a resident of the Canton of Fribourg/Freiburg. ${ }^{140}$

In the past years, three judges of courts of the Cantons were either not re-elected or chose to resign when facing the real possibility of being denied the re-election. The most prominent case was the one of Ziegler J, then President of the Court of Appeal of the Canton of Schwyz. In 2010, after information on two criminal cases had been leaked to the media, Ziegler $\mathrm{J}$ secretly ordered a surveillance of the telephone and e-mails of the public prosecutors involved in the two cases. When this became public, the parliamentary committee in charge of the elections of judges decided in January 2012 to recommend to the parliament not to re-elect Ziegler J. After Ziegler J had filed suit against the Canton, the parties settled the case and Ziegler J resigned. ${ }^{141}$

A judge in the Canton of Vaud was not re-elected in December 2012 by the parliament. To protect his privacy the parliament decided in a closed session. It was however publicly known that one of the reasons was that the judge had for years not paid his taxes. ${ }^{142}$

The third judge, a Court of Appeal judge in the Canton of Aargau, was the target of a number of complaints. An investigation revealed that he had serious deficits in organising his work. In the parliamentary debate, the judge was also alleged to be heavily in debt. The presiding judges of the Court of Appeal barely supported him, and so did the parliamentary committee on the judiciary, recommending his re-election with seven against six votes. The parliament's bureau, which comprises the presiding members of

139 See Constitution du canton de Fribourg 2010/Verfassung des Kantons Freiburg 2010, art 121(2) (translation: Constitution of the Canton of Fribourg).

140 Loi sur la justice du canton de Fribourg 2010/Justizgesetz des Kantons Freiburg 2010, art 107 (translation: Act on the judiciary of the Canton of Fribourg).

${ }^{141}$ Katharina Fontana "Abfindung ist korrekt" Neue Zürcher Zeitung (26 October 2013) at 14 (translation: "Severance payment is correct").

${ }^{142}$ Schweizerische Depeschen-Agentur "Waadtländer Richter abgewählt" St Galler Tagblatt Online (18 December 2012) <www.tagblatt.ch/aktuell/panorama/panorama/Waadtlaender-Richter-abgewaehlt; art253654,3241026> (translation: "Judge in the Canton of Vaud deselected"). 
the parliament and of its parties, however recommended not re-electing him. In the parliament only 48 out of 130 members voted to re-elect him. ${ }^{143}$

Where judges are elected and re-elected by the people, deselections occur presumably more often, as the people will be less considerate of the principle of judicial independence and instead focus more on party membership. On the other hand, as a rule in terms of elections, those already holding office have an advantage over their challengers since they are usually better known to the public. With regard to the effect on judicial independence, it could be argued that this kind of re-election does not prejudice judicial independence because a judge's deselection is usually not a consequence of his or her decisions. Instead, it is often quite simply a matter of their political party's electoral share decreasing in general.

\section{B. Obligations of Swiss judges vis-à vis their parties}

Another issue undermining judicial independence is that it is customary in Switzerland that political parties receive a share in what their members earn as public officials. This is referred to as "Mandatssteuern" ("contributions des élus", "contributi di mandato"), which could be translated as "taxation of mandate". Judges are deemed to be such public officials by the parties and are accordingly expected to pass on a part of their judicial salary. The exact amount varies: While some parties receive a fix amount, most will demand a percentage of the income, which may range between two and ten per cent.

These Mandatssteuern provide a substantial part of most parties' revenues. Accordingly, it is likely that the parties rely to some extent on receiving Mandatssteuern as part of their revenues. Generally, the parties on the left tend to be more dependent on income from their members since they will receive less sizable donations from big business. Presumably, the parties would therefore not tolerate if a judge refused to pay them. The judge's re-election would certainly be in danger. According to a newspaper article of 2012, most major parties experienced that judges would resign from the party

\footnotetext{
$\overline{{ }^{143} \text { Urs Moser "Abwahl von Oberrichter Schuppisser: Grünliberale beklagen Schlammschlacht” Aargauer }}$ Zeitung (20 August 2013) <http://www.aargauerzeitung.ch/aargau/kanton-aargau/artikel-127090472> (translation: "Deselection of Court of Appeal Judge Schuppisser: Green-liberal party complains about mudslinging)".
} 
and accordingly stop payment immediately after having been re-elected for the last time possible. $^{144}$

At the election day in 1990 when Schubarth J was refused re-election, another judge, Leu J, was only barely re-elected, receiving two more than the required 116 votes. One member of parliament alleged a week later that Leu $\mathrm{J}$ had received so few votes mainly because he had not paid his Mandatssteuern. ${ }^{145}$ According to a commentator however, Leu $\mathbf{J}$ had been criticised for acting as an arbitrator in arbitration cases in a sideline job at a time when the Federal Supreme Court was complaining about excessive workload. ${ }^{146}$

Whichever allegation concerning Leu $\mathrm{J}$ was true, there can be no doubt that the judges must feel some pressure to pay their Mandatssteuern if they do not want to endanger their re-election. However, a refusal of payment would presumably not be enough for the other parties to deselect a judge.

\section{A de facto tenure?}

Against this background, it could be argued that Swiss federal court judges enjoy a de facto tenure. This appears to be confirmed by the recent past:

Early in this millennium, the Federal Supreme Court had rendered three decisions that instigated public debates: The first two both concerned the question whether applications for the citizenship could be ruled on by holding a public vote. The Court held this to be unconstitutional. ${ }^{147}$ Both decisions were published in 2003.

A year later, the Court rendered an even more contested decision on the criminal liability of racist speeches. Since according to the Swiss Criminal Code racial

\footnotetext{
${ }^{144}$ Pascal Unternährer "Warum ausgerechnet die Unparteiischen in einer Partei sein müssen" TagesAnzeiger online (4 June 2012) <www.tagesanzeiger.ch/zuerich/region/Warum-ausgerechnet-dieUnparteiischen-in-einer-Partei-sein-muessen/story/23157169> (translation: "On why the impartial of all people need to be members of a party)".

145 Christoph Blocher (12 December 1990) Amtliches Bulletin der Vereinigten Bundesversammlung (translation: Official Protocol of the debates of the Federal Assembly) at 2521.

${ }^{146}$ Raul Lautenschütz "Mässiges Wahlergebnis für Bundespräsident Cotti: Bundesrichter Schubarth nicht bestätigt" Neue Zürcher Zeitung (Zurich, 6 December 1990) at 21 (translation: "Mediocre election result for Federal president Cotti: Federal Supreme Court judge Schubarth not re-elected").

${ }^{147}$ A v Municipality of Emmen [2003] 129 I BGE/ATF 217; Schweizerische Volkspartei der Stadt Zürich (SVP) v Municipality of Zurich [2003] 129 I BGE/ATF 232.
} 
discrimination was only criminally liable when committed publicly, ${ }^{148}$ the question presented to the Court was whether a meeting of skinheads in a forest cabin was "public" in the sense of the law. The Court did not apply definitions of "public" found in previous decisions and instead held that whatever was said outside of a strictly private setting was considered as "public". 149

All three decisions went against the policy of the SVP, which accordingly criticised the Court for the first two decisions, stating that they challenged the foundation of the direct democracy. ${ }^{150}$ While these decisions were thus criticised in a comparably civilised manner, a harsh reaction followed the last one. In a press release the SVP argued that, at the time the provision was enacted, the authorities had promised that the provision would only be applied where the public was highly affected. It thought that the Court was engaging in politics. At the end of the press release the SVP threatened with „einschneidenden Konsequenzen bei der nächsten Wahl des Bundesgerichts” ("serious consequences at the next re-election of the Federal Supreme Court"). ${ }^{151}$

The term of office turned out to be too long though. When the Federal Supreme Court judges were put up for re-election four years later, the wounds had apparently healed, and the judges who had participated in the decision were re-elected comfortably with results from 185 to 216 out of 224 votes. ${ }^{152}$

In 2010, the presiding judge of the Court's second division on social insurance law, Meyer J, had been prominently involved in a highly contested decision. ${ }^{153}$ In this case the Court, partly overruling its previous case law, made it nigh impossible for insured persons suffering from chronic whiplash injury to be granted a disability pension. The

\footnotetext{
${ }^{148}$ See Schweizerisches Strafgesetzbuch (translation: Swiss Crimina Code) 1937, art 261 bis.

${ }^{149}$ Public Prosecutor of the Canton of Bern v X [2004] 130 IV BGE/ATF 111 at 119.

150 SVP "SVP gegen Aushöhlung der Volksrechte" Schweizerische Volkspartei SVP <www.svp.ch/index.cfm/aktuell/medienmitteilungen/svp-gegen-aushoehlung-der-volksrechte/> (translation: "SVP against erosion of democratic rights").

151 SVP "Privatsphäre abgeschafft?" Schweizerische Volkspartei SVP <www.svp.ch/index.cfm/aktuell/medienmitteilungen/privatsphaere-abgeschafft/> (translation: "Abolition of privacy?").

${ }^{152}$ See (1 October 2008) Amtliches Bulletin der Vereinigten Bundesversammlung at 1589 (translation: Official Protocol of the debates of the Federal Assembly).

${ }^{153}$ IV-Stelle Lucerne v S [2010] 136 V BGE/ATF 279.
} 
decision had drawn much public criticism, part of which was aimed directly at Meyer $\mathbf{J}$ who had in 2010 published an essay, in which he had criticised the previous case law. ${ }^{154}$ At the re-election of 2014 however, no acts of retaliation against Meyer J occurred.

As stated above, the Federal Supreme Court from time to time faced the question whether Federal or international law prevails in case of conflict. ${ }^{155}$ Traditionally, the Court's case law held that international law should in principle prevail, except if the legislator intentionally enacted a Federal law that is in conflict with international law (Schubert case). ${ }^{156}$ In a number of recent cases though the Federal Supreme Court held that international law must prevail in cases where the international law is aimed at the protection of human rights (such as the European Convention on Human Rights). ${ }^{157}$

Of particular interest in this regard is the 2013 case $X v$ Canton of Thurgau, which was decided by the second division on public law of the Federal Supreme Court, by a panel of five judges consisting of Zünd, Seiler, Aubry Girardin, Donzallaz and Stadelmann $\mathrm{JJ}^{158}$. The appellant $\mathrm{X}$ was a Macedonian citizen who had immigrated to Switzerland in 1994 at the age of seven. In 2010 he had been convicted for dealing with heroin and sentenced to 18 months imprisonment. The immigration authorities therefore cancelled his residence permit in 2011. The Court upheld X's appeal against the decision of the immigration authorities. It found, considering all circumstances, that the decision interfered disproportionately with his right to respect his family life and was therefore in violation of art 8 of the ECHR. ${ }^{159}$

The Court then turned to art 121 of the Swiss Constitution, the relevant paragraphs 3 and 4 of which read as follows: ${ }^{160}$

\footnotetext{
${ }^{154}$ See Thomas Gächter and Dania Tremp "Praxisänderung zur Invalidenrente nach einem HWS-Trauma" (27 September 2010) Jusletter <www.jusletter.ch> at [1]-[3] and [57] (translation: "Change in the case law regarding disability pensions following a whiplash injury").

${ }^{155}$ See above at III.C.1.c).

${ }^{156}$ See Schubert $v$ Canton of Ticino, above $\mathrm{n} 23$.

${ }^{157}$ See $A v$ Federal Council, above n 24; Eidgenössische Zollverwaltung $v$ X, above n 24.

${ }^{158} X v$ Canton of Thurgau [2013] 139 I BGE/ATF 16.

${ }^{159}$ At $22-23$.

160 Bundesverfassung der Schweizerischen Eidgenossenschaft 1999, art 190 (translation: Federal Constitution of the Swiss Confederation) as per the semi-official translation on <http://www.admin.ch/opc/en/classified-compilation/19995395/index.html>.
} 
3 Irrespective of their status under the law on foreign nationals, foreign nationals shall lose their right of residence and all other legal rights to remain in Switzerland if they:

a. are convicted with legal binding effect of an offence of intentional homicide, rape or any other serious sexual offence, any other violent offence such as robbery, the offences of trafficking in human beings or in drugs, or a burglary offence; or

b. have improperly claimed social insurance or social assistance benefits.

4 The legislature shall define the offences covered by paragraph 3 in more detail. It may add additional offences.

Paragraphs 3 to 6 of art 121 of the Swiss Constitution had been inserted only very recently by way of a popular initiative, which had been approved in a public vote on 28 Nov 2010 by the majority of the people and the Cantons. The Court ruled that these provisions were not self-executing because they were too vague to be applied directly. ${ }^{161}$ It then went on to hold in an obiter dictum that - even if the provisions were applicablethe outcome of the case would remain the same because it would still be bound by art 8 of the ECHR when applying art 121 of the Swiss Constitution. ${ }^{162}$

The commentator for the newspaper Neue Zürcher Zeitung ${ }^{163}$ (NZZ) noted that in the public hearing one member of the Court had argued that art 121 of the Swiss Constitution should be applied and the appeal therefore dismissed. The majority, consisting of the other four members of the panel, however disagreed with him. ${ }^{164}$ While the NZZ did not mention the names of the five judges, and in particular the name of the dissenting judge, his identity is revealed by the later course of events to be Seiler J. Notably, Seiler J was one of two judges in the panel who are members of the SVP, which had proposed the new art 121 of the Swiss Constitution. The reason we can assume it to be Seiler $\mathbf{J}$ is as follows:

\footnotetext{
${ }^{161} \mathrm{X} v$ Canton of Thurgau, above $\mathrm{n} 158$, at 24-28.

162 At $28-31$.

163 Translation: New

164 Markus Felber "Verfassungsrechtlicher Diskurs mit Tiefgang" Neue Zürcher Zeitung (Zurich, 13 October 2012) at 15 (translation: "Constitutional law discourse with depth").
} 
When the written decision was published in early 2013, Seiler J's party, the SVP, criticised the decision in a press release as "subversive". ${ }^{165}$ However, they did not rest on that. In 2014, all Federal Supreme Court judges' term of office ended and the judges were accordingly to be re-elected by the Federal Assembly on 24 September 2014. The SVP chose not to re-elect the four judges that had decided to uphold the appeal because they wanted foreign law to prevail over domestic law, as one Councillor put it. ${ }^{166}$ While they did not officially announce this in Parliament, it became apparent in the election results of the judges. 224 of the 246 members of the Federal Assembly were present. Being the strongest party, the SVP currently holds 59 out of the 246 seats in the Federal Assembly. The SVP's position resulted in the four Judges Zünd, Aubry Girardin, Donzallaz and Stadelmann JJ receiving between 159 and 167 votes, the lowest numbers of votes of all 35 judges to be re-elected. ${ }^{167}$ All other judges received between 204 and 222 votes, with the exception of Seiler $\mathrm{J}$ at $198,{ }^{168}$ who did not enjoy the full support of the left-wing parties. ${ }^{169}$

There is no official information available on which councillors did or did not vote for particular judges. However, the election results suggest that the councillors who are members of the SVP abided rather strictly by their party's request, even though one of these four judges, Donzallaz J, is himself a member of the SVP.

What conclusions can be drawn from the recent events? The decisions presented above suggest that the Federal Supreme Court is not intimidated by upcoming reelections. A commentator noted in this regard shortly before the re-elections that these did not appear to seriously bother anyone at the Court. ${ }^{170}$ In particular the most recent

\footnotetext{
165 SVP "Bundesgericht will Volk und Parlament entmachten" Schweizerische Volkspartei SVP <www.svp.ch/index.cfm/aktuell/medienmitteilungen/bundesgericht-will-volk-und-parlament-entmachten/> (translation: "Federal Supreme Court wants to disempower the people and the parliament)".

166 Jan Flückiger "Parlament wählt zwei neue Bundesrichter" Neue Zürcher Zeitung (Zurich, 25 September 2014) at 12 (translation: "Parliament elects two new Federal Supreme Court judges)".

${ }^{167}$ See (24 September 2014) Amtliches Bulletin der Vereinigten Bundesversammlung at 1879 (translation: Official Protocol of the debates of the Federal Assembly).

168 At 1879.

${ }^{169}$ Flückiger, above n 166, at 12.

${ }^{170}$ Katharina Fontana "Die Frauen kommen" Neue Zürcher Zeitung (Zurich, 11 September 2014) at 10 (translation: "The women are coming").
} 
decision in the case $X v$ Canton of Thurgau seems to be testament to the Court being unaffected. In said case the Court was bold enough to express its opinion in an obiter dictum while the political debate on the implementation of art 121 of the Swiss Constitution was ongoing.

At the same time, the latest re-election results reveal that the largest political party in Switzerland, the SVP, which since 2003 has been receiving consistently more than $25 \%$ of the votes, does not care greatly about judicial independence. The question arises naturally what would happen if the SVP were to reach a majority. This however seems highly unlikely given that since 1919 no single party ever even reached an electoral share of $29 \% .^{171}$

\section{Discipline and removal from office of Swiss judges}

\section{Discipline and removal from office of Federal judges}

The Federal Assembly may remove judges from office before they completed their term in case of either misconduct or incabability. Misconduct is given, according to the pertinent provisions in all Federal acts, if a judge "wilfully or through gross negligence commits serious breaches of his or her official duties". ${ }^{172}$ Incapability is given if a judge "has permanently lost the ability to perform his or her official duties". ${ }^{173}$

The test of misconduct consists of two elements, both a subjective and an objective one. The objective element is the serious breach of an official duty, which may be any behaviour that seriously and objectively damages the reputation and independence of the

\footnotetext{
${ }^{171}$ See above at II.B.

172 Bundesgesetz über das Bundesverwaltungsgericht 2005, art 10(a) (translation: Federal Act on the Federal Administrative Court); Bundesgesetz über das Bundespatentgericht 2009 (translation: Federal Act on the Federal Patent Court), art 14(a); Bundesgesetz über die Organisation der Strafbehörden des Bundes 2010, art 49(a) (translation: Federal Act on the Organisation of the Federal Criminal Justice Authorities).

173 Bundesgesetz über das Bundesverwaltungsgericht 2005, art 10(b) (translation: Federal Act on the Federal Administrative Court); Bundesgesetz über das Bundespatentgericht 2009, art 14(b) (translation: Federal Act on the Federal Patent Court); Bundesgesetz über die Organisation der Strafbehörden des Bundes 2010, art 49(b) (translation: Federal Act on the Organisation of the Federal Criminal Justice Authorities).
} 
office. ${ }^{174}$ The subjective element requires that the judge committed the act either with intent or through gross negligence, thereby excluding slight negligence.

The Judiciary Committee will initiate proceedings if it finds, after the judge has been heard, that there is a reasonable suspicion that either of the two conditions for removal is satisfied. If the investigation reveals either misconduct or incabability as defined by the law, the Committee submits a written report to the Federal Assembly including a motion to remove the judge from office. ${ }^{175}$

The Federal Assembly has a certain amount of discretion, which is expressed in the wording that it "may" remove judges if the requirements are met. In a memorandum, the Ministry of Justice held that this discretion should be exercised in order to uphold the principle of proportionality. ${ }^{176}$ The decision of the Federal Assembly may not be brought before a court pursuant to the constitution, which states in art 189(4) that Acts of the Federal Assembly may not be challenged in the Federal Supreme Court.

These rules apply to all federal judges except for the Federal Supreme Court judges who are immune from discipline, as will be shown below.

In a 2003 report, the Ministry of Justice held the lack of judicial review to be in line with the European Convention on Human Rights (ECHR). It found the right to a fair trial disputes concerning "civil rights and obligations" as guaranteed in art 6(1) ECHR did not apply to the removal of judges. ${ }^{177}$ When reaching this conclusion, it relied on a decision of the European Court on Human Rights in Pitkevich v Russia, which held, applying its Pellegrin $v$ France judgment ${ }^{178}$, that a "judge participates directly in the exercise of

${ }^{174}$ Bundesamt für Justiz Amtspflichten der Richterinnen und Richter der erstinstanzlichen Bundesgerichte (VPB 2008.24) at 313 (translation: Federal Office of Justice Official duties of federal judges).

175 Handlungsgrundsätze der Gerichtskommission zum Verfahren der Kommission im Hinblick auf eine Amtsenthebung oder eine Nichtwiederwahl 2011, art 5-14 (translation: Principles of action of the Judiciary Committee for the Committee's procedure regarding removal or refusal of re-election).

${ }^{176}$ Bundesamt für Justiz (translation: Federal Office of Justice), above n 174, at 314.

177 Bundesamt für Justiz Richterliche Unabhängigkeit Disziplinarische Verantwortlichkeit von Bundesrichtern Amtsenthebung Neue gesetzliche Massnahmen Schlichtungsverfahren Selbstregulierung und Konfliktlösungsmöglichkeiten des Bundesgerichts (VPB 68.49 2003) at n 46 (translation: Federal Office of Justice Judicial Independence Discipline of Federal Supreme Court Judges Removal from Office New legal measures Self-regulation and conflict resolution of the Federal Supreme Court).

${ }^{178}$ Pellegrin v France (1999) 31 EHRR 651 (Grand Chamber, ECHR). 
powers conferred by public law and performs duties designed to safeguard the general interests of the State“. ${ }^{179}$ Consequently, a judge's dismissal was found not to concern her civil rights or obligations within the meaning of art $6(1)$ of the ECHR. ${ }^{180}$ However, Pellegrin is not anymore good law in determining whether employment disputes concerning public servants fall within the scope of art 6(1) of the ECHR: In the case of Eskelinen $v$ Finland, the Court found that the criterion adopted in Pellegrin needed to be further developed. ${ }^{181}$ It held: ${ }^{182}$

In order for the exclusion to be justified, it is not enough for the State to establish that the civil servant in question participates in the exercise of public power or that there exists, to use the words of the Court in Pellegrin, a "special bond of trust and loyalty" between the civil servant and the State, as employer. It is also for the State to show that the subject matter of the dispute in issue is related to the exercise of State power or that it has called into question the special bond. Thus, there can in principle be no justification for the exclusion from the guarantees of Article 6 of ordinary labour disputes, such as those relating to salaries, allowances or similar entitlements, on the basis of the special nature of relationship between the particular civil servant and the State in question.

The Court has ever since reiterated that two conditions must be fulfilled in order for art 6(1) of the ECHR not to apply: ${ }^{183}$

Firstly, the State in its national law must have expressly excluded access to a court for the post or category of staff in question. Secondly, the exclusion must be justified on objective grounds in the State's interest.

Swiss legal scholars concluded in 2008 that the consequences of Eskelinen v Finland on the status of judges were unclear. ${ }^{184}$ In the case of Suküt $v$ Turkey, which concerned an applicant that had been discharged from the army for breaches of discipline, the Court found that the "special bond of trust and loyalty" was at the heart of the dispute. ${ }^{185}$ It

\footnotetext{
${ }^{179}$ Pitkevich v Russia Section II, ECHR 47936/99, 8 February 2001 at 8.

180 At 8.

${ }^{181}$ Eskelinen v Finland (2007) 45 EHRR 43 (Grand Chamber, ECHR) at [56].

182 At [62].

183 Cudak v Lithuania (2010) 51 EHRR 15 (Grand Chamber, ECHR) at [42].

${ }^{184}$ Regina Kiener and others Verfahren der Erneuerungswahl von Richterinnen und Richtern des Bundes (VPB 2008.26) at 364 (translation: Procedure of re-election of federal judges).

185 Suküt v Turkey Section II, ECHR 59773/00, 11 September 2007 at 8.
} 
seems that the same could be said of proceedings to remove a judge from office for breaches of official duties.

Therefore, in this author's opinion, the exclusion of a judicial review in art 189(4) of the Bundesverfassung is not in violation of art 6(1) of the ECHR. It might, however, constitute a violation of art 13 of the ECHR. This article provides that:

Everyone whose rights and freedoms as set forth in this Convention are violated shall have an effective remedy before a national authority notwithstanding that the violation has been committed by persons acting in an official capacity.

In one of its leading cases on art 13 of the ECHR, de Souza Ribeiro v France, the Court held: ${ }^{186}$

The Court has reiterated on numerous occasions that Article 13 of the Convention guarantees the availability at national level of a remedy to enforce the substance of the Convention rights and freedoms in whatever form they are secured in the domestic legal order. The effect of this Article is thus to require the provision of a domestic remedy allowing the competent national authority both to deal with an "arguable complaint" under the Convention and to grant appropriate relief.

In order to be able to invoke the guarantee provided in art 13 of the ECHR a person must present an "arguable claim" of a violation of the ECHR. Should a judge who has been removed from office be able to make it plausible that his or her right to respect for private and family life or the freedoms of thought, conscience and religion, of expression or of assembly and association were violated, then a domestic remedy must be available. ${ }^{187}$ While the "authority" referred to in art 13 of the ECHR does not necessarily have to be a judicial authority, it must nevertheless be independent and the remedy must be effective. ${ }^{188}$ Given that Swiss legislation provides no domestic remedy whatsoever there can be no doubt that Switzerland would be in violation of art 13 of the ECHR should such a case occur.

While Federal judges may be removed from office in case of serious misconduct, they are not subject to discipline for minor misconduct.

\footnotetext{
186 de Souza Ribeiro v France Grand Chamber, ECHR 22689/07, 13 December 2012 at [78].

${ }^{187}$ Kiener and others, above n 184, at 366.

188 de Souza Ribeiro v France, above n 186, at [79].
} 


\section{No discipline or removal from office of Federal Supreme Court judges}

Federal Supreme Court judges are immune from any kind of discipline and can accordingly not be removed from office. ${ }^{189}$ In this regard, their position is similar to the one of Federal Councillors. ${ }^{190}$ They are expected to resign on their own initiative should they be guilty of a misconduct that is incompatible with their position. ${ }^{191}$ The lack of remedy in case of a Federal Supreme Court judge's misconduct or incapability was drawn to the public's attention when Federal Supreme Court judge Martin Schubarth was accused and found guilty of misconduct in 2003.

Schubarth J, being dissatisfied with the coverage of the court's case law by the Swiss newspaper "Neue Zürcher Zeitung", apparently tried to spit on a journalist working for said newspaper within the confines of the court's building. He missed his target and instead hit a law clerk whom the journalist was talking to. At the same time accusations were made that Schubarth $\mathrm{J}$ had misused his powers as the presiding judge of the criminal division of the court. ${ }^{192}$

The Federal Supreme Court confirmed the spitting incident in a press release and decided not to allocate Schubarth $\mathbf{J}$ any more cases. The Court called on Schubarth $\mathbf{J}$ to resign immediately. Schubarth J declined to do so. ${ }^{193}$

The incident and the accusations were then investigated by a parliamentary commission, which found that Schubarth $\mathbf{J}$ had in one case declared a judgment as unanimous even though one of the three judges had announced his dissent. ${ }^{194}$ It was held that the spitting incident constituted a gross breach of manners that did not go along with

\footnotetext{
${ }^{189}$ Bundesamt für Justiz (translation: Federal Office of Justice), above n 177, at ch II131.

${ }^{190}$ See above at II.A.

${ }^{191}$ Geschäftsprüfungskommissionen des Nationalrates und des Ständerates Untersuchung von besonderen Vorkommnissen am Bundesgericht (BBl 2004 5647) at 5683 (translation: Audit Commission of the Federal Parliament Investigation of special occurrences at the Federal Supreme Court).

192 Geschäftsprüfungskommissionen des Nationalrates und des Ständerates Jahresbericht 2002/2003 der Geschäftsprüfungskommissionen und der Geschäftsprüfungsdelegation der eidgenössischen Räte (BB1 2004 1637) at 1706 (translation: Audit Commission of the Federal Parliament Annual Report of the Audit Commission and the Audit Delegation of the Federal Parliament 2002/2003).

${ }^{193}$ At 1706.

${ }^{194}$ At 1707.
} 
the position of a Federal Supreme Court judge. ${ }^{195}$ The commission noted that Federal Supreme Court judges are not subject to disciplinary authority. ${ }^{196}$ It called on Schubarth J to resign, which he eventually did.

The case of Schubarth $\mathrm{J}$ remains the sole incident of that kind involving a federal judge. No other federal judge was forced to resign or removed from office yet.

\section{Discipline and removal from office in the Cantons}

Most Cantons have adopted the rule that a judge may be removed from office in case of misconduct and incapability. The Canton of Bern has added the case of permanent insufficient performance as a further ground for removal.

The power to remove a judge lies with different authorities. In most Cantons, the power is granted either to the parliament, the court of appeal or the presiding judges of the court of appeal.

In case of a removal of a judge from a court of first instance, the competent authority is usually the court of appeal or its presiding judges. If the judge to be removed from office is a court of appeal judge, then usually either the administrative court, if any, or the parliament will make the decision. The Canton of Bern has opted for the first system, in which the Court of Appeal has the power to discipline Administrative Court judges and the Administrative Court has the power to discipline Court of Appeal judges.

An example for the latter system, where the decision is made by the parliament, is found in the Cantons of Basel-Stadt and Basel-Landschaft. In these cases the law of the Canton must allow an appeal from the parliament's decision to a court as a matter of Federal law. ${ }^{197}$ While the Federal law allows an exception for decisions having a predominantly political character, a judge's removal from office does not fall in that

197 Bundesgesetz über das Bundesgericht 2005, art 86(2) (translation: Federal Act on the Federal Supreme Court).
} 
category. ${ }^{198}$ Not all Cantons appear to be aware of that rule, as the laws of some Cantons provide for a "final decision" of the parliament. ${ }^{199}$

The Canton of Aargau, in its reform of the judiciary in 2011, appears to have installed what could be called the most modern system of removal of judges. At the core of this system is the establishment of a specialised court to deal with such matters: The Justizgericht ("judiciary court"). While minor disciplinary matters are dealt with by a special committee consisting of three judges of the Court of Appeal, the Justizgericht is the sole court in the Canton to decide on the removal of judges. ${ }^{200}$ It consists of three judges that are elected by the parliament. They are the only judges at courts in the Canton of Aargau who are not required to be residents of Aargau and for whom no age limit has been set. $^{201}$ The latter rule reflects the legislator's idea that the Justizgericht should be composed of experienced lawyers.

\section{E. Discipline and removal from office of New Zealand judges}

In New Zealand, the powers and procedures to discipline judges are codified in the Judicial Conduct Commissioner and Judicial Conduct Panel Act 2004 (JCCJCPA). ${ }^{202}$ This Act established the Office of the Judicial Conduct Commissioner as the authority to conduct preliminary investigations of complaints against judges. The commissioner is appointed by the Governor-General on the recommendation of the House of Representatives and after consultation of the Chief Justice. ${ }^{203}$ Having investigated the complaint, the commissioner has four options of how to go on:

\footnotetext{
198 Bundesgesetz über das Bundesgericht 2005, art 86(3) (translation: Federal Act on the Federal Supreme Court).

199 See Loi sur la justice du canton de Fribourg 2010/Justizgesetz des Kantons Freiburg 2010, art 109 (translation: Act on the judiciary of the Canton of Fribourg).

200 Gerichtsorganisationsgesetz des Kantons Aargau 2011, § 38(1)(a) (translation: Act on the organisation of the judiciary of the Canton of Aargau).

201 Gerichtsorganisationsgesetz des Kantons Aargau 2011, § 16(1) and § 18(3) (translation: Act on the organisation of the judiciary of the Canton of Aargau).

202 Joseph, above n 61, at 73.

203 Judicial Conduct Commissioner and Judicial Conduct Panel Act 2004, s 7.
} 
a) take no further action, if further consideration of the complaint would be unjustified ${ }^{204}$

b) dismiss the complaint, if it fails to meet the required threshold; ${ }^{205}$

c) refer the complaint to the Head of Bench, unless one of the other three options are selected; 206

d) recommend the appointment of a Judicial Conduct Panel, if an inquiry is justified and the alleged conduct is misconduct that may warrant consideration of removal from office. ${ }^{207}$

If a complaint has substance, the "default option" is referral to the Head of Bench. ${ }^{208}$ Given that the Head of Bench has no disciplinary powers over other judges, ${ }^{209}$ his or her findings are not binding on the judge.

The most important distinction is made between complaints alleging minor misconduct and complaint alleging serious misbehaviour, that is misbehaviour that may warrant consideration of removal from office. ${ }^{210}$ In the latter case, the commissioner recommends that the Attorney-General appoint a Judicial Conduct Panel to investigate into the alleged misconduct and report on it to the Attorney-General. ${ }^{211}$ The members of the panel, of which one must be a layperson and the other two must be judges or retired judges or one (retired) judge and one legal practitioner, are appointed ad hoc by the Attorney-General ${ }^{212}$ after consultation with the Chief Justice. ${ }^{213}$ While the panel's report must include its opinion as to whether consideration of removal of the Judge is justified, ${ }^{214}$ the Attorney-General enjoys absolute discretion in deciding on whether to

\footnotetext{
204 Judicial Conduct Commissioner and Judicial Conduct Panel Act, s 15A.

205 Judicial Conduct Commissioner and Judicial Conduct Panel Act, s 16.

206 Judicial Conduct Commissioner and Judicial Conduct Panel Act, s 17.

207 Judicial Conduct Commissioner and Judicial Conduct Panel Act, s 18.

208 Joseph, above n 61, at 74; Wilson v Attorney-General NZHC 1678, [2011] 1 NZLR 399 at [42].

209 Joseph, above n 61, at 72 and 74.

210 At 73.

211 Judicial Conduct Commissioner and Judicial Conduct Panel Act, s 22 and 24.

212 Judicial Conduct Commissioner and Judicial Conduct Panel Act, s 22(1).

213 Judicial Conduct Commissioner and Judicial Conduct Panel Act, s 21(2).

214 Judicial Conduct Commissioner and Judicial Conduct Panel Act, s 32(2).
} 
press for removal. ${ }^{215}$ However, a judge must not be removed from office if the panel did not consider removal justified. ${ }^{216}$

If the Attorney-General agrees with the panel, he or she will take steps to initiate the removal of that Judge from office. While the procedure to be followed depends on whether the judge is a superior court judge or an inferior court judge, the actual removal lies in both cases in the hands of the Governor-General. ${ }^{217}$

Where an inferior court judges is concerned, the Governor-General must, by constitutional convention, act on the advice of the Attorney-General. ${ }^{218}$ The decision is therefore the Attorney-General's whether to seek the judge's removal. In contrast, superior court judges can only be removed upon address of the House of Representatives. $^{219}$ The same holds true, in an anomaly, for Employment Court judges. ${ }^{220}$ In these cases, the Attorney-General accordingly has to address Parliament, which then decides having exclusive cognisance whether to seek the judge's removal. ${ }^{221}$

As to the threshold that needs to be met for removal the High Court cited approvingly from a Privy Council decision ${ }^{222.223}$

So important is judicial independence that removal of a judge can only be justified where the shortcomings of the judge are so serious as to destroy confidence in the judge's ability properly to perform the judicial function.

The High Court rejected the assertion that misbehaviour necessarily involves moral turpitude. $^{224}$

Both the commissioner's recommendation ${ }^{225}$ and the Attorney-General's decision to appoint a panel are susceptible to judicial review in the High Court. ${ }^{226}$ The same holds

\footnotetext{
215 Judicial Conduct Commissioner and Judicial Conduct Panel Act, s 33(1).

216 Judicial Conduct Commissioner and Judicial Conduct Panel Act, s 33(2).

${ }^{217}$ District Courts Act 1947 s 7(1).

${ }^{218}$ Joseph, above n 61, at 80.

${ }^{219}$ Constitution Act 1986 s 23.

${ }^{220}$ Joseph, above n 61, at 80 .

${ }^{221}$ At 89.

${ }^{222}$ Hearing on the Report of the Chief Justice of Gibraltar [2009] UKPC 43.

${ }^{223}$ Wilson v Attorney-General, above n 208, at [62]

${ }^{224}$ At [66].

${ }^{225}$ At [50].
} 
true for the decision of the Governor-General to remove the judge, ${ }^{227}$ whereas the decision of the House of Representatives as a proceeding in Parliament is immune from judicial scrutiny. ${ }^{228}$ This immunity is thought to extend to the Attorney-General's decision whether to move an address. ${ }^{229}$

Regardless of the threshold that needs to be met, New Zealand judges enjoy a remarkable "procedural" security from unjustified attacks: Removal from office requires that both the commissioner and the Attorney-General agree that the alleged conduct justifies investigation by a panel and that the panel, the Attorney-General, a majority of the House of Representatives ${ }^{230}$ and the Governor-General find the conduct to justify removal.

The establishment of the commissioner and the panel makes perfectly sense in terms of having independent investigators. In contrast, the Attorney-General's absolute discretion in determining whether or not removal is justified seems questionable. What if an Attorney-General, despite a panel's conclusion, declined to initiate the removal of a judge whom that very Attorney-General had appointed? Nevertheless, there is some logic to the involvement of the Attorney-General and the Governor-General, as "the prerogative to appoint judges imports also the prerogative to remove judges". 231

The odd one out of the involved authorities is the House of Representatives. There are undoubtedly good reasons not to involve the Parliament when appointing judges and the very same reasons are no less valid when it comes to removing judges. The decision whether to dismiss a judge should, if anything, be less informed by political considerations than the decision whether to appoint a judge.

The involvement of the House, the most political institution in the country, is perhaps best explained as deeply rooted in history: It dates back to the beginning of the eighteenth century, when it was established in the United Kingdom that senior judges could only be

\footnotetext{
${ }^{226}$ At [144].

${ }^{227}$ Joseph, above n 61, at 89.

228 At 89.

${ }^{229}$ At 89.

${ }^{230}$ As far as a superior court judge is concerned.

${ }^{231}$ Joseph, above n 61, at 77.
} 
dismissed by a motion of both houses of Parliament. ${ }^{232}$ Accordingly, before the JCCJCPA was enacted in 2004 the removal from office of judges was a matter of the exclusive cognisance of Parliament. An address seeking to remove a judge from office could be moved by any Member of Parliament. ${ }^{233}$

The parliamentary debates reveal that some Members of Parliament were hard pressed to accept losing their right to move an address for a judge's removal from office, as evidenced by a statement of Richard Worth MP: 234

I also resent the fact that a right I have as a member of Parliament to move an address seeking the removal of a judge is to be taken away from me and other members of the House.

Against this background, the reform implemented through the enactment of the JCCJCPA appears to be a prudent way of reducing Parliament's discretion by tying it to both an investigation by a panel and an address by the Attorney-General without taking the ultimate decision away from Parliament.

For the aforementioned reasons it seems inappropriate too that in Switzerland the Federal Assembly is competent to decide on removing federal judges, even though this is consistent with the axiom that "the prerogative to appoint judges imports also the prerogative to remove judges". ${ }^{235}$ While there is some force to this axiom in principle, it does not extend to jurisdictions such as Switzerland where judicial appointments are made by political bodies following political considerations. The decision on whether removal from office is justified is strictly a matter of the law's interpretation and application. The requirements that need to be met are clearly stated in legislation and there are no political implications to be considered. Such decisions should not be made by parliaments but by bodies that are trained and appointed to do just that: courts of law.

\footnotetext{
232 Kate Malleson "Appointment, discipline and removal of judges: fundamental reforms in the United Kingdom" in HP Lee (ed) Judiciaries in Comparative Perspective (Cambridge University Press, Cambridge, 2011) 117 at 127.

233 Joseph, above n 61, at 76-77.

234 (12 May 2004) 617 NZPD 12875.

235 See above n 231.
} 


\section{Conclusions}

New Zealand inherited the English tradition that the judicial bench is reserved for experienced lawyers who are appointed based on merit alone. This provides for a judiciary where the standard of quality is consistently high even in the inferior courts.

Switzerland on the other hand traditionally embraced the view that anybody whom the people (or the parliament as their representatives) deem worthy may be a judge. This has endowed Switzerland's lower courts with a wide range of judges from laypersons to respected lawyers. Over time, the standards for judges were raised because the parties became more and more aware of the importance judges having experience in the legal profession, yet lay judges are still found at many lower courts and even some higher courts of the Cantons.

The criteria for selecting the judges are naturally not identical in the two countries. New Zealand judges are appointed based on merit. Even though the appointments are effectively made by a politician, they are not made in a political role, and party politics apparently play no part at all. In contrast, Switzerland selects its judges openly following political considerations, which this author submits is not as bad as it sounds. Switzerland has always aimed at all major political tendencies taking part in the exercise of the power of the state. Accordingly, as a matter of tradition, the courts are usually composed of a number of judges who, ideally, display the range of political tendencies in the society. This paper argues that having a diversity of political views at the courts is beneficial in terms of "justice seen to be done", as it may counteract perceptions of the judiciary as a self-perpetuating oligarchy.

That being said, there is no persuasive argument-or argument at all, for that matter - in favour of restricting the pool of candidates to members of the political parties since party membership is not common in Switzerland: Only about 3\% of the citizens are members of a political party. While an argument could be made that some judges are not party members but merely declare to sympathise with a party, this still leaves out all politically neutral candidates_-arguably those who are best suited to be a judge.

Unlike New Zealand judges, Swiss judges (with the exception of the Canton of Fribourg/Freiburg) are not granted the security of tenure but are elected for a comparably 
short term of office. This is of course undermining judicial independence as it creates opportunities for politicians to retaliate against inconvenient judges.

Nevertheless, in the past Swiss judges arguably enjoyed a de facto tenure: While legislation has always left room for pressure on judges with the need of re-election, the parliaments have been aware of their responsibility to safeguard the judges' independence. In the last few decades though, the tonality in federal politics has become harsher, and this extends to the tonality chosen by politicians versus judges. An increasing number of politicians can no longer be trusted to give preference to judicial independence over their political agenda. At the same time, the available evidence in the form of both case law and journalists' observations suggests that Swiss judges are anything but intimidated.

Against this background, a reform of the Swiss system of election and re-election of judges would certainly be preferable. It is, however, not likely to happen, as the political parties are the ones that benefit most from the current system-both by being able to select the judges and by receiving a share of their judges' incomes.

A comparison of the procedures to be followed in order to remove a judge from office reveals a high level of protection for New Zealand judges. The recent reform in 2004 restricted the once unlimited power of Parliament by subjecting it to a prior investigation and an address by the Attorney-General. This fascinating approach ensures that, while Parliament has the final say, both the judicature (through the investigation of the Judicial Conduct Panel) and the executive (through the Attorney-General as member of the Government) are involved in the process.

On balance, while the New Zealand judiciary thus enjoy a great amount of protection, there is ultimately much power concentrated in the person of the Attorney-General who decides both on whom to appoint and on whom to subject to a removal from office by Parliament. This should however not distract from the fact that New Zealand has found sound solutions for the problems posed by the appointment, discipline and removal of judges. 


\section{BIBLIOGRAPHY}

\section{PRIMARY SOURCES}

\section{A Cases}

$1 \quad$ New Zealand

Wilson v Attorney-General NZHC 1678, [2011] 1 NZLR 399.

2 European Court of Human Rights

Pellegrin v France (1999) 31 EHRR 651 (Grand Chamber, ECHR).

Pitkevich v Russia Section II, ECHR 47936/99, 8 February 2001.

Eskelinen v Finland (2007) 45 EHRR 43 (Grand Chamber, ECHR).

Suküt v Turkey Section II, ECHR 59773/00, 11 September 2007.

Cudak v Lithuania (2010) 51 EHRR 15 (Grand Chamber, ECHR).

Xv Canton Thurgau [2013] 139 BGE 16 (Switzerland Federal Supreme Court).

de Souza Ribeiro v France Grand Chamber, ECHR 22689/07, 13 December 2012.

$3 \quad$ Switzerland

A v Federal Council [1999] 125 II BGE/ATF 417.

A v Municipality of Emmen [2003] 129 I BGE/ATF 217.

Eidgenössische Zollverwaltung $v$ X [2012] 138 II BGE/ATF 524.

IV-Stelle Lucerne v S [2010] 136 V BGE/ATF 279.

Klee v Liberal-Democratic Party of the District of Werdenberg [1976] 102 Ia BGE/ATF 264.

Municipality of Cadro v Bernasconi [1990] 116 Ia BGE/ATF 252.

Public Prosecutor of the Canton of Bern v X [2004] 130 IV BGE/ATF 111.

Rohner v Canton of Appenzell Innerrhoden [1990] 116 Ia BGE/ATF 359.

Schweizerische Volkspartei der Stadt Zürich (SVP) v Municipality of Zurich [2003] 129 I BGE/ATF 232.

Schubert v Canton of Ticino [1973] 99 Ib BGE/ATF 39. 
Xv Canton of Thurgau [2007] 134 I BGE/ATF 16.

Xv Canton of Thurgau [2013] 139 I BGE/ATF 16.

4 Gibraltar

Hearing on the Report of the Chief Justice of Gibraltar [2009] UKPC 43.

$5 \quad$ United Kingdom

$R v$ Sussex Justices, ex parte McCarthy [1924] 1 KB 256 (CA).

\section{B Legislation}

$1 \quad$ New Zealand

Constitution Act 1986.

District Courts Act 1947.

Judicature Act 1908.

Judicial Conduct Commissioner and Judicial Conduct Panel Act 2004.

Supreme Court Act 2003.

$2 \quad$ Switzerland

\section{a Federation}

Bundesverfassung der Schweizerischen Eidgenossenschaft 1999.

Bundesgesetz über das Bundesgericht 2005.

Bundesgesetz über das Bundespatentgericht 2009.

Bundesgesetz über das Bundesverwaltungsgericht 2005.

Bundesgesetz über die Bundesversammlung 2002.

Bundesgesetz über die Organisation der Strafbehörden des Bundes 2010.

Handlungsgrundsätze der Gerichtskommission zum Verfahren der Kommission im Hinblick auf eine Amtsenthebung oder eine Nichtwiederwahl 2011.

Schweizerisches Strafgesetzbuch 1937.

\section{b Cantons}

Constitution de la République et canton de Genève 2012.

Constitution du canton de Fribourg 2010/Verfassung des Kantons Freiburg 2010. 
Costituzione della Repubblica e Cantone Ticino 1997.

Gerichtsorganisationsgesetz des Kantons Aargau 2011 (translation: Act on the organisation of the judiciary of the Canton of Aargau).

Loi sur la justice du canton de Fribourg 2010/Justizgesetz des Kantons Freiburg 2010.

\section{SECONDARY SOURCES}

\section{A Books and chapters in books}

Allan, James "Judicial Appointments in New Zealand: if it were done when 'tis done, then 'twere well it were done openly and directly" in Kate Malleson and Peter H Russell (eds) Appointing Judges in an Age of Judicial Power: Critical Perspectives from around the World (University of Toronto Press, Toronto, 2006) 103.

Heimgartner, Stefan "Der Richter und sein Schreiber (translation: The judge and his clerk)" in Marianne Heer and others (eds) Toujours agité - jamais abattu: Festschrift für Hans Wiprächtiger (translation: Always agitated - never disheartened: Festsschrift for Hans Wiprächtiger) (Helbing Lichtenhahn, Basel, 2011) 295.

Joseph, Philip A “Appointment, discipline and removal of judges in New Zealand" in HP Lee (ed) Judiciaries in Comparative Perspective (Cambridge University Press, Cambridge, 2011) 66.

Malleson, Kate "Appointment, discipline and removal of judges: fundamental reforms in the United Kingdom" in HP Lee (ed) Judiciaries in Comparative Perspective (Cambridge University Press, Cambridge, 2011) 117.

Ministry of Justice Appointing Judges: A Judicial Appointments Commission for New Zealand? (Ministry of Justice, Wellington, 2004).

Palmer, Geoffrey "Judicial Selection and Accountability: Can the New Zealand System Survive?" in B D Gray and R B McClintock (eds) Courts and Policy: Checking the Balance (Brooker's, Wellington, 1995) 11.

Webb, Duncan, Sanders, Katherine and Scott, Paul The New Zealand Legal System: Structures and Processes (5th ed, LexisNexis, Wellington, 2010).

\section{B Journal articles}

Cooke, Robin "Empowerment and Accountability: The Quest for Administrative Justice" (1992) 18 Commonwealth Law Bulletin 1326.

Gibbons, Thomas “The rise of Judges' Clerks” [2002] NZLJ 136.

Kiener, Regina "Richterwahlen in der Schweiz” [2002] 71 Betrifft JUSTIZ 378. 
McGrath, John “Appointing the Judiciary” [1998] The New Zealand Law Journal 314.

Raselli, Niccolo "Richterliche Unabhängigkeit" (2011) 3 Justice - Justiz - Giustizia $<$ www.richterzeitung.ch>.

\section{Parliamentary and government materials}

$1 \quad$ New Zealand

\section{a Hansard}

(12 May 2004) 617 NZPD 12874-12897.

\section{b Government materials}

Crown Law Office Judicial Appointments Protocol (Crown Law Office, 2014).

Ministry of Justice Judicial Appointments: Office of District Court Judge(2012).

$2 \quad$ Switzerland

\section{a Parliamentary transcripts}

(12 December 1990) Amtliches Bulletin der Vereinigten Bundesversammlung 25212524.

(1 October 2008) Amtliches Bulletin der Vereinigten Bundesversammlung 1589-1590.

(25 September 2013) Amtliches Bulletin der Vereinigten Bundesversammlung 17841785.

(24 September 2014) Amtliches Bulletin der Vereinigten Bundesversammlung 18791880 .

(6 December 2001) Amtliches Bulletin des Ständerates 904-925.

\section{b Select committee reports}

Gerichtskommission Vorbereitung der Wahlen an das Bundesverwaltungsgericht (2006) $<$ www.parlament.ch/d/organe-mitglieder/kommissionen/weitere-kommissionen/ gerichtskommission/Documents/gk-rueckblick-2011-2013-d.pdf>.

Gerichtskommission Bericht der Gerichtskommission vom 8 Dezember 2011 (11.210 b) <www.parlament.ch/sites/kb/2012/Kommissionsbericht_GK_12.200_2012-03-07.pdf>.

Geschäftsprüfungskommissionen des Nationalrates und des Ständerates Untersuchung von besonderen Vorkommnissen am Bundesgericht (BB1 2004 5647).

Geschäftsprüfungskommissionen des Nationalrates und des Ständerates Jahresbericht 2002/2003 der Geschäftsprüfungskommissionen und der Geschäftsprüfungsdelegation der eidgenössischen Räte (BB1 2004 1637). 
Sekretariat der Gerichtskommission Die Gerichtskommission der Vereinigten Bundesversammlung während der ersten Hälfte der 49 Legislaturperiode, 2011 - 2013 (2013) <www.parlament.ch/d/organe-mitglieder/kommissionen/weitere-kommissionen/ gerichtskommission/Documents/gk-rueckblick-2011-2013-d.pdf >.

\section{Reports}

$1 \quad$ New Zealand

Law Commission Delivering Justice For All: A Vision for New Zealand Court and Tribunals (R85 2004).

Law Commission Review of the Judicature Act 1908: Towards a new Courts Act (R126 2012).

Office of the Minister of Justice Government response to the Law Commission's report "Review of the Judicature Act 1908: towards a new Courts Act" (2013).

\section{$2 \quad$ Switzerland}

Bundesamt für Justiz Richterliche Unabhängigkeit Disziplinarische Verantwortlichkeit von Bundesrichtern Amtsenthebung Neue gesetzliche Massnahmen Schlichtungsverfahren Selbstregulierung und Konfliktlösungsmöglichkeiten des Bundesgerichts (VPB (2003) 68.49).

Bundesamt für Justiz Funktion der Gerichtskommission der Vereinigten Bundesversammlung Vorbereitung von Richterwahlen (VPB (2003) 69.3).

Bundesamt für Justiz Amtspflichten der Richterinnen und Richter der erstinstanzlichen Bundesgerichte (VPB 2008.24).

Bundesgericht Stellungnahme des Bundesgerichts vom 23 Februar 2001 (BB1 2001 5890).

Bundesrat Botschaft über eine neue Bundesverfassung (BB1 1997 1).

Kiener, Regina and others Verfahren der Erneuerungswahl von Richterinnen und Richtern des Bundes (VPB 2008.26).

\section{E Newspaper articles}

Bruggisser, Kurt "Zur Abwahl von Martin Schubarth" Neue Zürcher Zeitung (6 December 1990).

Felber, Markus "Problematische Kür der Richter in der Schweiz" Neue Zürcher Zeitung (31 December 2009) at 11.

Felber, Markus "Verfassungsrechtlicher Diskurs mit Tiefgang” Neue Zürcher Zeitung (13 October 2012). 
Flückiger, Jan "Parlament wählt zwei neue Bundesrichter" Neue Zürcher Zeitung (25 September 2014).

Fontana, Katharina “Abfindung ist korrekt” Neue Zürcher Zeitung (26 October 2013).

Fontana, Katharina “Die Frauen kommen” Neue Zürcher Zeitung (11 September 2014).

Hürlimann, Brigitte "Der Polizist will nicht mehr richten” Neue Zürcher Zeitung (16 May 2014).

Jankovsky, Peter "Das Tessinervolk redet vor Gericht mit" Neue Zürcher Zeitung (13 December 2011).

Lautenschütz, Raul "Mässiges Wahlergebnis für Bundespräsident Cotti: Bundesrichter Schubarth nicht bestätigt” Neue Zürcher Zeitung (6 December 1990).

\section{F Internet Resources}

Bundesgericht "Schweizerisches Bundesgericht - Richter und Personal" <www.bger.ch/index/federal/federal-inherit-template/federal-richter.htm>.

Gächter, Thomas and Tremp, Dania "Praxisänderung zur Invalidenrente nach einem HWS-Trauma” (27 September 2010) Jusletter <www.jusletter.ch>.

Grossrieder, Beat and Strebel, Dominique "Justiz: Die Laien sterben langsam aus (translation: Judiciary: The laypersons are dying out)" Beobachter $<$ www.beobachter.ch/justiz-behoerde/buerger-verwaltung/artikel/justiz_die-laien-sterbenlangsam-aus/>.

Kley, Andreas Historisches Lexikon der Schweiz/Dictionnaire historique de la Suisse (online ed, 2014) Bundesstaat <http://www.hls-dhs-dss.ch/textes/d/D9801.php>.

Moser, Urs "Abwahl von Oberrichter Schuppisser: Grünliberale beklagen Schlammschlacht (translation: Deselection of Court of Appeal Judge Schuppisser: Greenliberal party complains about mudslinging)" Aargauer Zeitung (20 August 2013) <http://www.aargauerzeitung.ch/aargau/kanton-aargau/artikel-127090472>.

Netzle, Simon "Der Gerichtsschreiber - mehr Gericht als Schreiber? (translation: The Court Clerk - more Court than Clerk?)" <www.gerichtsschreiber.ch/pdf/geschichtliches.pdf>.

Schweizerische Depeschen-Agentur "Waadtländer Richter abgewählt (translation: Judge in the Canton of Vaud deselected)" St Galler Tagblatt Online (18 December 2012) <http://www.tagblatt.ch/aktuell/panorama/panorama/Waadtlaender-Richterabgewaehlt;art253654,3241026>.

SVP "SVP gegen Aushöhlung der Volksrechte (translation: SVP against erosion of democratic rights)" $\quad$ Schweizerische Volkspartei $\quad$ SVP 
$<$ http://www.svp.ch/index.cfm/aktuell/medienmitteilungen/svp-gegen-aushoehlung-dervolksrechte/>.

SVP "Privatsphäre abgeschafft? (translation: Abolition of privacy?)" Schweizerische Volkspartei <http://www.svp.ch/index.cfm/aktuell/medienmitteilungen/privatsphaere-abgeschafft/>.

SVP "Bundesgericht will Volk und Parlament entmachten (translation: Federal Supreme Court wants to disempower the people and the parliament)" Schweizerische Volkspartei SVP <http://www.svp.ch/index.cfm/aktuell/medienmitteilungen/bundesgericht-will-volkund-parlament-entmachten/>.

Taylor, Phil "Justice in the firing line" New Zealand Herald (5 May 2012) <http://www.nzherald.co.nz/nz/news/article.cfm?c_id=1\&objectid=10803600>.

Unternährer, Pascal "Warum ausgerechnet die Unparteiischen in einer Partei sein müssen" Tages-Anzeiger online (4 June 2012) <www.tagesanzeiger.ch/zuerich/ region/Warum-ausgerechnet-die-Unparteiischen-in-einer-Partei-sein-muessen/story/ $23157169>$.

Wikipedia „Swiss Federal Council election“ <http://en.wikipedia.org/wiki/Federal Council_Switzerland_election> 